Florida International University

FIU Digital Commons

FIU Electronic Theses and Dissertations

University Graduate School

3-31-2011

\title{
Constructing a Revolutionary Narrative: Black Liberation and the Political Uses of the Past in the United States and South Africa, 1960-1975
}

Douglas Jones

Florida International University, djone013@fiu.edu

DOI: $10.25148 /$ etd.FI1 1051003

Follow this and additional works at: https:// digitalcommons.fiu.edu/etd

\section{Recommended Citation}

Jones, Douglas, "Constructing a Revolutionary Narrative: Black Liberation and the Political Uses of the Past in the United States and South Africa, 1960-1975" (2011). FIU Electronic Theses and Dissertations. 399.

https://digitalcommons.fiu.edu/etd/399 


\title{
FLORIDA INTERNATIONAL UNIVERSITY \\ Miami, Florida
}

\begin{abstract}
CONSTRUCTING A REVOLUTIONARY NARRATIVE: BLACK LIBERATION AND THE POLITICAL USES OF THE PAST IN THE UNITED STATES AND SOUTH AFRICA, 19601975
\end{abstract}
A thesis submitted in partial fulfillment of the requirements for the degree of MASTER OF ARTS
in HISTORY
by

Douglas Robert Jones 
To: Dean Kenneth Furton

College of Arts and Sciences

This thesis, written by Douglas Robert Jones, and entitled Constructing a Revolutionary Narrative: Black Liberation and the Political Uses of the Past in the United States and South Africa, 1960-1975, having been approved in respect to style and intellectual content, is referred to you for judgment.

We have read this thesis and recommend that it be approved.

Alexandra Cornelius-Diallo

Jean Rahier

Alex Lichtenstein, Major Professor

Date of Defense: March 31, 2011

The thesis of Douglas Robert Jones is approved.

\begin{tabular}{r} 
Dean Kenneth Furton \\
College of Arts and Sciences \\
\hline Interim Dean Kevin O’Shea \\
University Graduate School
\end{tabular}

Florida International University, 2011 


\section{ACKNOWLEDGMENTS}

I would like to thank the members of my committee-Drs. Alex Lichtenstein, Alexandra Cornelius-Diallo and Jean Rahier-for their support and constructive critiques of the thesis. 


\begin{abstract}
OF THE THESIS
CONSTRUCTING A REVOLUTIONARY NARRATIVE: BLACK LIBERATION AND THE

POLITICAL USES OF THE PAST IN THE UNITED STATES AND SOUTH AFRICA, 1960-
\end{abstract}

1975

by

Douglas Robert Jones

Florida International University, 2011

Miami, Florida

Professor Alex Lichtenstein, Major Professor

This thesis fills a gap in the existing historiography of comparative AmericanSouth African history. Using primary source documents such as trial testimony, newspapers, books, memoirs, and poetry, this thesis compares the ways in which African and African American activists remembered their past and deployed it in the context of Umkhonto we Sizwe (MK) and the Black Power movement. Both movements seized upon particular memories of the anti-colonial struggle of the nineteenth century and of slave revolts, respectively. In keeping with their policy of non-racialism, MK looked to a variety of colonial wars waged by Xhosa, Zulu, and other African states. Black Power activists challenged depictions of contented slaves in a bid to reclaim their history from their oppressors. At a broader theoretical level, this thesis demonstrates that memory is strongly implicated in race-making and protest movements. 


\section{TABLE OF CONTENTS}

CHAPTER

PAGE

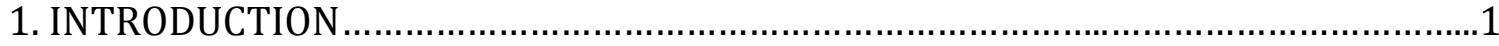

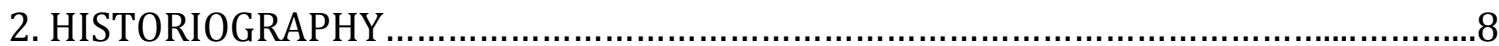

3. MANDELA, MK, AND THE POLITICAL USES OF THE PAST IN SOUTH AFRICA......33

4. BLACK POWER AND THE POLITICAL USES OF THE PAST IN THE UNITED

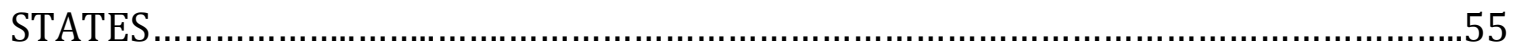

5. CONCLUSION

BIBLIOGRAPHY 


\section{Introduction}

Nelson Mandela had never been in the armed forces, and when it came time in the early 1960s to abandon non-violent protest in favor of planning an armed revolution, Mandela turned to the African past. As a guide to the present, Mandela "studied our history both before and after the white man. I probed the wars of African against African, of African against white, of white against white." In choosing a name for the new organization, Mandela reached back to the pre-colonial past. The symbol of the spear-Umkhonto we Sizwe translates as The Spear of the Nationwas chosen "because with this simple weapon Africans had resisted the incursions of whites for centuries."1

At the moment that the civil rights movement in the United States began to abandon its own commitment to non-violent struggle, the intellectuals and activists Stokely Carmichael and Charles Hamilton did not advocate guerrilla warfare in their seminal work on Black Power, but they did forewarn against its possibility. The anticolonial intellectual Frantz Fanon, whom Carmichael and Hamilton quote in their preface, observed in his influential book, The Wretched of the Earth, that violence "governed the ordering of the colonial world" and violence would thus be necessary to dismantle it. ${ }^{2}$ The most essential part of Carmichael's call for cultural nationalism was "to reclaim our history and our identity from what must be called cultural

\footnotetext{
${ }^{1}$ Nelson Mandela, Long Walk to Freedom: The Autobiography of Nelson Mandela (New York: Little, Brown, and Company, 1994), 274-275.

2 Frantz Fanon, The Wretched of the Earth, translated by Richard Philcox, (New York: Grove Press, 1961), 4.
} 
terrorism."3 If cultural nationalism was a response to "cultural terrorism" then a policy of non-violence could not remain on the table.

The black liberation struggles of South Africa and the United States both took a turn toward militancy or even outright violence in the 1960s. ${ }^{4}$ Black South Africans made the first move. Following the Sharpeville massacre of March 21, 1960, in which South African police opened fire on a peaceful group of protestors, a group of African National Congress (ANC) members led by Nelson Mandela formed the military wing of the ANC and founded Umkhonto we Sizwe (MK, or sometimes UMK) after they were convinced of the futility of peaceful campaigning in ending the brutal system of Apartheid. Likewise, following what was seen as the inadequacy of the Civil Rights Act of 1964 and the Voting Rights Act of 1965 in alleviating the situation of African Americans-particularly in the northern ghettoes-who were still subject to police brutality and poverty and social isolation, black nationalists like Stokely Carmichael advocated revolution, including violence if necessary.

\footnotetext{
${ }^{3}$ Stokely Carmichael and Charles V. Hamilton, Black Power: The Politics of Liberation (New York: Random House, 1967), 34.

${ }^{4}$ I use the term violence to describe both situations, although the meaning is not precisely the same. First of all it is to be distinguished from state sanctioned violence. In South Africa, violence manifested as a sabotage campaign against the Apartheid state that aimed to minimize bloodshed and foment a widespread social revolution. In the United States, violence manifested as armed self-defense, or in some cases, revolutionary socialism. Recently historians have been reexamining the place of violence in American history. Michael Fellman has argued that terrorism in the nineteenth century amounts "to a counternarrative of American national development, a story characterized by extreme political violence at critical junctures." See Michael Fellman, In the Name of God and Country: Reconsidering Terrorism in American History (New Haven: Yale University Press, 2010), 232.
} 
Much could be made of both the differences and similarities between the two situations. Both ideological and strategic turns took place following a violent engagement with white police: in South Africa, the aforementioned Sharpeville massacre; in the United States, the rioting in the Watts neighborhood of south Los Angeles, as well as the brutality meted out to civil rights marchers in places like Selma, in the spring and summer of 1965 also played a role. While black South Africans had made no meaningful legal progress against Apartheid, the turn to militancy in the United States came on the heels of two very important pieces of federal legislation, and over a decade after the end of legal segregation with Brown v. Board of Education in 1954. As the above quotations from Carmichael and Mandela make clear, whatever their current situation, both groups looked decisively toward the past as their guide, inspiration, and rhetorical tool. Further, activists in both the United States and South Africa actively combated what could be considered hegemonic forms of white collective memory.

The significant degree to which both groups turned to the past at key moments in their historical development is the primary argument of this thesis. It is a fact that has been largely overlooked and under analyzed by historians. But as Maurice Halbwachs showed to be true of collective memory, the past is not a given: "the past is not preserved but is reconstructed on the basis of the present." ${ }^{5}$ Comparing the memory invoked and constructed by both the civil rights movement

\footnotetext{
${ }^{5}$ Maurice Halbwachs, On Collective Memory, translated by Lewis A. Coser (Chicago: University of Chicago Press, 1992), 40.
} 
and anti-apartheid movements is instructive and confirms Halbwachs' observation. African Americans and black South Africans looked primarily to their own history and rejected or even denigrated dominant strains of white collective memory particular to their own situation. Both groups were highly selective in the choice and interpretation of that history. In South Africa, this meant turning to the colonial and even pre-colonial past and discarding the memory of the non-violent, often Gandhian-influenced recent past. Similarly in the United States, Black Power activists turned to the colonial and slave past, emphasizing the role of slave revolts, for example. Both groups said little about the role of women in fighting white supremacy, although thinkers like Angela Davis did take up the issue.

While both American and South African protest leaders may have been attempting to tap into a widely circulating collective memory and also reject white collective memory, the thinkers and leaders here are not involved in collective memory traditionally understood. Indeed, as Arjun Appadurai has argued based on south Indian fieldwork, the past can only be stretched so far, and limits exist on the ability of the past to be infinitely deployed. The past is not a "boundless canvas for contemporary embroidery" but is better viewed as a finite commodity. ${ }^{6}$

Susan Crane has argued that although scholars of collective memory have been skeptical of historical consciousness because of its self-reflexivity, she asks, "when, in fact, has collective memory ever been uttered if not individually?" Crane

${ }^{6}$ Arjun Appadurai, "The Past as a Scarce Resource," Man, New Series, Vol. 16, No. 2 (Jun., 1981), 201-219. 
argues that even self-reflexive historical research is consciously integrated into collective memory. ${ }^{7}$ The memory work the actors in this thesis engage in confirm both Appadurai and Crane's insights. The narratives they deploy are neither wholly constructed, nor can they be considered "facts" in the positivist sense. Rather, thinkers like Mandela and Malcolm X drew from particular symbolic repertoires. Mandela was relating the collective memory that he grew up with in the Transkei, but his strategic use of praise singers and wearing a kaross can also be read as attempt to tap into the collective memory of the ANC's supporters, and potential supporters. As Appadurai argued, memory has a strong relation to power, but memory cannot be constructed out of whole cloth.

The comparison historians often make in this era is between Black Power in the United States and Black Consciousness in South Africa. ${ }^{8}$ In many ways Black Consciousness followed the thinking of Black Power leaders like Stokely Carmichael, whose words Steve Biko used nearly verbatim in South Africa a few years later. ${ }^{9}$ Naturally, comparing two related phenomena becomes tricky, when it is difficult to distinguish between what is uniquely "American" or "South African" about each case. While Black Power thinkers were well aware of the situation in South Africa, there is

\footnotetext{
${ }^{7}$ Susan Crane, "Writing the Individual Back into Collective Memory," American Historical Review, Vol. 102, No.5 (Dec., 1997), 1382.

${ }^{8}$ George Fredrickson, Black Liberation: A Comparative History of Black Ideologies in the United States and South Africa (New York: Oxford University press, 1995), 277318.

${ }^{9}$ Daniel Magaziner, The Law and the Prophets: Black Consciousness in South Africa, 1968-1977 (Athens: Ohio University Press, 2010), 50.
} 
no evidence that they drew from that situation in any meaningful way. The comparison on offer here compares two far more discrete histories. In many ways MK and Poqo (the armed wing of the ANC's nationalist rival, the Pan Africanist Congress) offer a better comparison with Black Power as both turned to violence. Black Consciousness formed in the aftermath of the Rivonia trials that concluded MK's sabotage campaign and accordingly focused on cultivating psychic, rather than material change, at least in the short run. The importance of class struggle is also more central to the ANC and Black Power than it was to Black Consciousness, which tended to be more concerned with spiritual rather than material poverty. As Steve Biko remarked, "Material want is bad enough, but coupled with spiritual poverty it kills. And this latter effect is probably the one that creates mountains of obstacles in the normal course of emancipation of the black people."10

By putting the construction of historical memory in the revolutionary rhetoric of the post-1965 Black Power movement and the ANC's turn to armed struggle in comparative perspective, this thesis begins to address some major historiographical holes. While it importantly puts memory into a comparative framework, it also demonstrates how memory is an important method of excavating

\footnotetext{
10 Steve Biko, I Write What I Like: Selected Writings (Chicago: University of Chicago Press, 1978), 28. On the subject of Black Consciousness, see particularly Gail M. Gerhart, Black Power in South Africa: The Evolution of an Ideology (Berkeley: University of California Press, 1978), Robert Fatton, Black Consciousness in South Africa: the Dialectics of Ideological Resistance to White Supremacy (Albany: State University of New York Press, 1986), and Daniel R. Magaziner, The Law and the Prophets: Black Consciousness in South Africa, 1968-1977 (Athens: Ohio University Press, 2010).
} 
black subjectivity across the African diaspora. Memories of and during Apartheidera South Africa, as well as of slavery in the United States, are often said to be memories of gaps, silences, or taboos. ${ }^{11}$ During the tumult of the 1960 s and early 1970s, however, memory could both be constructed on the page and embodied in song, dress, and emotion. While the ANC and the Black Panthers wrote about the past in their newspapers and pamphlets, memory was also worn on the body, or experienced by many who felt that the distinction between past and present was growing ever thinner. This latter collapse was no doubt a response to the high emotional tenor of the times but also a function of the way subaltern groups deployed memory as a commodity in a bid to unseat their oppressors.

${ }^{11}$ See Helena Pohlandt-McCormick, 'I Saw a Nightmare...' Doing Violence to Memory: The Soweto Uprising, June 16, 1976 (Columbia University Press, 2006) www.gutenberg-e.org/pohlandt-mccormick and James Horton and Lois Horton, eds., Slavery and Public History: The Tough Stuff of American Memory (New York: New Press, 2006). 


\section{Historiography}

This project lies at the intersection of four historiographies. The first and most significant is the now decades-long attempt pioneered by George Fredrickson to compare the establishment and destruction of systems of racial domination in the United States and South Africa. The second and most theoretical historiography is the study of collective memory, a recurring theme in both American and South African history, yet a theme which has not been studied comparatively. ${ }^{12}$ Third and fourth, this project aims to bring the theoretical lenses of comparison and collective memory to bear on the anti-Apartheid struggle as well as the Black Power movement.

While Fredrickson's multiple comparative studies of the United States and South Africa mark the beginning of the historical profession's interest in the subject, the comparison's origins can be traced much farther back to thinkers who confronted the issues of segregation in both societies in the early $20^{\text {th }}$ century. ${ }^{13}$ The first study to explicitly make this comparison and to gain a wide audience was Maurice Evans' 1915 study Black and White in the Southern States. Evans' 1914

\footnotetext{
12 This lacuna is not true of other cross-national comparisons. See Wolfgang Schivelbusch, The Culture of Defeat: On National Trauma, Mourning, and Recovery (New York: Metropolitan Books, 2001). Schivelbusch compares the experience of the American South with Germany and France.

13 Howard Lamar and Leonard Thompson predate this by only a year. See Howard Lamar and Leonard Thompson, The Frontier in History: North America and Southern Africa Compared (New Haven: Yale University Press, 1981). Lamar and Thompson also ratify the liberal thesis that white supremacy can be traced to the frontier rather than the mineral revolution around the turn of the twentieth century.
} 
travels through the American South were intended to inform similar policies of racial segregation in South Africa, yet remain an important source about the American South to this day. ${ }^{14}$

Writing in the comparative tradition pioneered by Frank Tannenbaum's 1947 Slave and Citizen, Fredrickson's first work on comparative American and South African history was White Supremacy: A Comparative Study in American and South African History. ${ }^{15}$ While White Supremacy's import should not be minimized, its shortcomings should be emphasized. Fredrickson's Americanist training is on display here. Fredrickson was writing on the cusp of the radical turn in South African historiography, and White Supremacy is now clearly showing its age. While Americanists have typically been very attuned to regional differences, White Supremacy offers a cautionary lesson in the perils of letting one region-in this case, the Western Cape and the South Africa frontier-stand in for others. Perhaps the most important takeaway from White Supremacy, however, is Fredrickson's insistence that comparison need not equate to mere similarity. Indeed, Fredrickson argues that the difference that most surprised Maurice Evans in 1914 was the lack

\footnotetext{
${ }^{14}$ Maurice S. Evans, Black and White in the Southern States: A Study of the Race Problem in the United States from a South African Point of View (London: Longmans, Green and Co., 1915).

${ }^{15}$ Frank Tannenbaum, Slave and Citizen (New York: Knopf, 1947), George Fredrickson, White Supremacy: A Comparative Study of American and South African History (Oxford: Oxford University Press, 1981).
} 
of a legal economic color bar in the American South—even at the height of Jim Crow - a feature that made the two historical situations quite different. ${ }^{16}$

At the time, Fredrickson was forthcoming about what is easily the greatest lacuna of his work. Describing his focus on the "dominant whites", he pointed out that "[t]his approach has obvious limitations. Comparative studies of non-white responses and resistance movements would be enormously valuable and should be done. But a useful prelude to such a work is awareness of what nonwhites were up against, and this is what I have tried to convey." ${ }^{17}$ While the present study is consciously responding to this request, Fredrickson himself was the first to take up the challenge in 1995 with Black Liberation: A Comparative History of Black Ideologies in the United States and South Africa. ${ }^{18}$ In part spurred by the unexpectedly quick and relatively peaceful transition to multiracial democracy in South Africa, Fredrickson argued that unlike the respective systems of white domination, "black" protest had "much similarity" in both countries. ${ }^{19}$ Black is in quotation marks here, because as Fredrickson emphasizes, when speaking of protest against systems of white domination, it is hardly the case that all involved share some essential blackness. In South Africa in particular, the existence of not only those of Bantu descent, but Cape Coloureds, Indians and other groups

\footnotetext{
16 Fredrickson, 236.

17 Ibid., $\mathrm{xx}$.

18 George Fredrickson, Black Liberation: A Comparative History of Black Ideologies in the United States and South Africa, (Oxford: Oxford University Press, 1995). 19 Ibid., 5.
} 
complicate this picture. This is an essential point which, as this thesis will demonstrate, also complicated attempts to construct a shared past.

The fundamental similarities Fredrickson saw in the two struggles for black liberation caused him to "retreat somewhat from the claim in White Supremacy that demographic differences come close to obviating useful comparisons of black-white relations in twentieth century America and South Africa." ${ }^{20}$ As he points out, the term "minority" is a problematic one-while African Americans were and are a demographic minority in the United States, the same is not true of South Africa. However, in the field of power relations, blacks under Apartheid were woefully underrepresented. This shift in Fredrickson's thought with respect to the fundamental comparison at hand is inevitable when, as so many other scholars have done, "white domination" and "black liberation" are treated as discrete and historically separate phenomena. That is, only by considering race relations as a dialectic is it possible to fully understand the evolution of those relations. ${ }^{21}$

This white action, black reaction schema is evident in the overall structure of both White Supremacy and Black Liberation. A great deal of White Supremacy is spent considering the question of to what degree racial segregation is a holdover from the colonial past (an emphasis that derives, in part, from the focus on the expanding Cape frontier). Indeed, the book ends with the era of segregation roughly

\footnotetext{
20 Fredrickson, Black Liberation, 6.

21 On this point, see Frederick Cooper, "Race, Ideology, and the Perils of Comparative History,” The American Historical Review, Vol. 101, No. 4 (Oct., 1996), 1122-1138.
} 
in the middle of the twentieth century, having begun in the seventeenth. Conversely, Fredrickson begins Black Liberation with a discussion of suffrage as a central aim of black liberation struggles. He notes in merely a sentence that this emphasis on suffrage was true only after slavery in the United States and intact indigenous societies in South Africa were no longer in force. It is telling that Fredrickson left such a question of the colonial holdovers out of Black Liberation.

In contrast to Fredrickson and published shortly after White Supremacy, John Cell's The Highest Stage of White Supremacy: The Origins of Segregation in South Africa and the American South persuasively made the case that segregation was, in both countries, a response to modernization and was far from an inevitable outgrowth of slavery and colonialism. ${ }^{22}$ The Highest Stage of White Supremacy remains a useful survey of the development of segregation in both countries, and Cell's depiction of segregation is far more detailed than Fredrickson's, and all the more persuasive for it. While Fredrickson was forthcoming about his lack of attention to black protest, Cell relegates discussion of black protest to the final chapter. Where other chapters, particularly in those on the American history of segregation, Cell's discussion was sharp and nuanced, the discussion of black protest is shallow, and almost an afterthought.

By comparison, in a single volume, Anthony Marx entered into both the debates over American and South African comparative history as well as, going back

${ }^{22}$ John W. Cell, The Highest Stage of White Supremacy: The Origins of Segregation in South Africa and the American South (Cambridge: Cambridge University Press, 1982). 
to Tannenbaum, that of the United States and Brazil. In so doing, Marx may well have created his own comparison: comparative South African and Brazilian history. A political scientist with a strong historical bent, Marx's interest is in what Theda Skocpol and Margaret Somers have termed "macro-causal analysis" which resembles "multivariate hypothesis-testing." ${ }^{23}$ Accordingly, Marx's thesis is that where the United States and South Africa both institutionalized and legalized racial domination, no such legal system was constructed in Brazil. As a result, de facto racial domination in Brazil was much more difficult to unite and mobilize against. Implicitly, however, Marx is adding to the case to be made for similarities between the South African and American experiences.

Finally, Marx goes one important conceptual step past Fredrickson. Where the dialectics of race making from above and below are separate in Fredrickson, Marx stresses that "Just as the construction of racial orders emerged from a dynamic of nation building from above and real or potential challenges from below, changes in those racial orders emerged from the same general dynamic." 24 Few would argue with this statement, yet when it comes to structuring his study, Marx is little better than Fredrickson. Making Race and Nation is divided into three sections: "Historical and Cultural Legacies", "Racial Domination and the Nation-State", and "Race Making from Below." In the first section, Marx correctly points out that slavery and

${ }^{23}$ Theda Skocpol and Margaret Somers, "The Uses of Comparative History in Macrosocial Inquiry," Comparative Studies in Society and History, Vol. 22, No. 2 (Apr., 1980), 175.

${ }^{24}$ Anthony Marx, Making Race and Nation: A Comparison of the United States, South Africa, and Brazil, (New York: Cambridge University Press, 1998), 269. 
colonialism did not foreordain the legal orders that would emerge after abolition,

but does not say what role actions of slaves, for instance, had on the emerging legal order. Likewise, the separation between the last two sections on race-making from above and below also fail to speak to the dynamic of construction and change Marx referred to above. As Marx points out in the beginning of that final section, race making from above and below "emerge in an ongoing dialogue." ${ }^{25}$ However, "Race Making from Below" begins only with the dawn of the twentieth century-what impact race making from below had before that, Marx does not say. ${ }^{26}$

\section{Memory}

Over the course of the last decade, there has been a surge of interest in collective memory as it relates to major issues of race in both the United States and

25 Marx., 191.

${ }^{26}$ For other important work on US-South African comparative history, see Howard Lamar and Leonard Thompson, The Frontier in History: North American and Southern Africa Compared (New Haven: Yale University Press, 1981); Stanley B. Greenberg, Race and State in Capitalist Development: Comparative Perspectives (New Haven: Yale University Press, 1980); Ran Greenstein, Comparative Perspectives on South Africa (Basingstoke: Macmillan Press, Ltd., 1998); and Peter Alexander and Rick Halpern, "Comparing Race and Labour in South Africa and the United States," Journal of Southern African Studies, Vol. 30, No. 1, Special Issue: Race and Class in South Africa and the United States (Mar., 2004), 5-18. There has also been a great deal of attention recently to the transnational history of South Africa and the United States. See Stéphane Robolin, "Remapping South African and African American Cultural Imaginaries," in Jean Rahier et al, eds., Global Circuits of Blackness: Interrogating the African Diaspora (Urbana: University of Illinois Press, 2010), 127151; James Campbell, Songs of Zion: The African Methodist Episcopal Church in the United States and South Africa (New York: Oxford University Press, 1995); James Campbell, Middle Passages: African American Journeys to Africa, 1787-2005 (New York: The Penguin Press, 2006). For a thoughtful critique of comparative history, see Micol Siegel, "Beyond Compare: Comparative Method after the Transnational Turn," Radical History Review Issue 91 (Winter 2005), 62-90. 
South Africa. This small but growing literature has been highly selective in its choice of subjects, however. In large measure, the choice of subjects is not surprising. In the United States, collective memory of the Civil War and to a lesser degree, emancipation, along with memory of the Civil Rights movement have been in the foreground of scholarship. Surely these are two signal events in American history, and likewise, the question of how the end of Apartheid in South Africa has been remembered has been fruitfully pondered by many South African scholars-not just historians. ${ }^{27}$

While historians of the United States and especially of the American South are beginning to reverse this trend, the dominant thrust of work on memory has been to focus on "white" memory. This trend is most apparent in the historiography of the "Lost Cause," which examines the ways white Southerners in the New South constructed a memory of the Civil War stressing the honor and nobility of their cause-states' rights—and downplaying the issue of slavery. ${ }^{28}$

\footnotetext{
${ }^{27}$ See for instance Jacquelyn Dowd Hall, "The Long Civil Rights Movement and the Political Uses of the Past," The Journal of American History, Vol. 91, No. 4 (Mar., 2005), 1233-1263, Renée Romano and Leigh Raiford, eds., The Civil Rights Movement in American Memory (Athens: University of Georgia Press, 2006), Sabine Marschall, Landscape of Memory: Commemorative monuments, memorials and public statuary in post-apartheid South-Africa (Leiden: Brill, 2010).

${ }^{28}$ On the myth of the Lost Cause, see especially William C. Davis, The Cause Lost: Myths and Realities of the Confederacy (Lawrence, Kansas: University Press of Kansas, 1996), Gaines Foster, Ghosts of the Confederacy: Defeat, the Lost Cause, and the Emergence of the New South, 1865-1913 (Oxford: Oxford University Press, 1988), Charles Reagan Wilson, Baptized in Blood: The Religion of the Lost Cause, 1865-1920 (Athens: University of Georgia Press, 1980), Anne E. Marshall, Creating a Confederate Kentucky: The Lost Cause and Civil War Memory in a Border State
} 
Easily the best and most powerful of the recent works on collective memory in the United States is David Blight's 2001 Race and Reunion: The Civil War in American Memory. ${ }^{29}$ Blight's thesis is that in the process of building a new nation after the Civil War, North and South joined together once again but in the process excluded African Americans from that national vision. Accordingly, the way contemporaries at the turn of the twentieth century remembered that war and its attendant social transformation were highly racialized. Northern and Southern whites alike could remember the war as an issue of states' rights having little to do with slavery. Blight offers less detail on African American memory of the war, however, devoting only a single chapter to it. He usefully identifies three overlapping strains of black memory: a progressive, accommodationist memory that viewed the slave past almost as a "paralytic burden"; a millenialist and Ethiopianist vision of the future in which the end of slavery was but one step along the way to a black nationalist future; and a patriotic memory that celebrated sacrifice to the Union, and thus encouraged blacks to participate in building a new nation. ${ }^{30}$ At least around the turn of the century, it is clear from Blight's account that Emancipation Day was the primary occasion for African-American

(Chapel Hill: University of North Carolina Press, 2010). On recent popular manifestations, see Tony Horowitz, Confederates in the Attic: Dispatches from the Unfinished Civil War (New York: Vintage, 1998).

${ }^{29}$ David W. Blight, Race and Reunion: The Civil War in American Memory (Cambridge: Harvard University Press, 2001).

30 Blight, 300. 
remembrance. Ida Wells, for example, used history to ground her rhetoric of progress in her anti-lynching campaign.

For all of its brilliance, Race and Reunion remains short on detail on AfricanAmerican memory. Two years later, Mitch Kachun published a much more detailed study based on his doctoral dissertation titled Festivals of Freedom: Memory and Meaning in African American Emancipation Celebrations, 1808-1915. ${ }^{31}$ Where Blight saw overlapping strands of memory, Kachun sees tension: the tension between Americanness and distinctiveness, as well as the tension between holding onto the past and discarding the pain that could come with it. ${ }^{32}$ Though Kachun does not say so, it is useful to think of the former tension as an analogue to, and perhaps a source for, later debates over liberalism versus black nationalism. Kachun has a more functionalist view of freedom festivals: they provided an important opportunity for education and for organization. The narrative begins in 1808 with the closing of the Atlantic slave trade, a novel departure from the Civil War as starting point. The meaning of this connection-which transcends the usual dividing line in American history-is unfortunately not explored. ${ }^{33}$

${ }^{31}$ Mitch Kachun, Festivals of Freedom: Memory and Meaning in African American Emancipation Celebrations, 1808-1915 (Amherst: University of Massachusetts Press, 2003).

32 Ibid., 13.

${ }^{33}$ For a regional study of Emancipation Day celebrations, see Paul Ortiz's work on Florida in Paul Ortiz, Emancipation Betrayed: The Hidden History of Black Organizing and White Violence in Florida from Reconstruction to the Bloody Election of 1920 (Berkeley: University of California Press, 2005), Ch. 4, "To Gain These Fruits That Have Been Earned", 85-100. 
More recently, Margot Minardi has taken up the issue of race and memory in the context of early nineteenth century Massachusetts. In a state that was (and is) full of nostalgia for the revolutionary past, Minardi examines how abolitionists contested this memory in an effort to end slavery in that state. More than Kachun, Minardi connects the contesting of history to political outcomes. ${ }^{34}$

Looking forward from emancipation, two recent monographs can be usefully read together to see how two very different gendered tropes survived into the twentieth century. Scot French's The Rebellious Slave traces the ways that Nat Turner's 1831 rebellion has been both invoked and silenced over the following century and a half. ${ }^{35}$ French's study does not analyze the gendered dimensions of Turner's rebellion as thoroughly as it might have; this becomes more apparent when paired with Micki McElya's study of the trope of the faithful slave in twentieth century America.

While McElya uses the general term "slave" in the title, Clinging to Mammy is focused specifically on African American women, and for good reason. Where French only alludes to the gendered dimension of Turner's rebellion and its controversial recreation in William Styron's 1967 novel, The Confessions of Nat Turner, McElya demonstrates how the myth of the faithful mammy presented

\footnotetext{
${ }^{34}$ Margot Minardi, Making Slavery History: Abolitionism and the Politics of Memory in Massachusetts (New York: Oxford University Press, 2010).

${ }^{35}$ Scot French, The Rebellious Slave: Nat Turner in American Memory (Boston: Houghton Mifflin Company, 2004). Also see Merrill D. Peterson, John Brown: The Legend Revisited (Charlottesville: University of Virginia Press, 2002).
} 
unique challenges for laboring African American women. ${ }^{36}$ As McElya points out, there was little similarity between the situation of enslaved women and women who worked as domestics in the twentieth century. But given the curious ways that collective memory functions, this did not stop many whites, like the United Daughters of the Confederacy, from embracing the myth. The myth resulted, among other things, in the acceptability of offering non-cash wages to domestic workers. Among other contests, McElya interprets the Montgomery Bus Boycott of 1955 as African American women rejecting the myth of the faithful mammy.

Jumping forward to the twenty-first century, there is also a small but growing literature on the collective memory of the civil rights movement itself. ${ }^{37}$ Recently Jacquelyn Dowd Hall has written an article that both captures and critiques these trends..$^{38}$ Originally delivered as a presidential address to the Organization of American Historians, Hall identifies two strands of memory of the civil rights movement that are at odds with one another. Popular memory of the civil rights movement builds on earlier journalistic accounts, and tends to refer only to a ten

\footnotetext{
${ }^{36}$ William Styron, The Confessions of Nat Turner: A Novel, (New York: Random House, 1967), Micki McElya, Clinging to Mammy: The Faithful Slave in Twentieth-Century America (Cambridge: Harvard University Press, 2007).

${ }^{37}$ One example which includes a wide variety of work is Renée Romano and Leigh Raiford, eds., The Civil Rights Movement in American Memory (Athens: University of Georgia Press, 2006). Also see Owen Dwyer and Derek Adelman, Civil Rights Memorials and the Geography of Memory (Athens: University of Georgia Press, 2008), and David A. Zonderman, review of the Martin Luther King Jr. National Historic Site, The Journal of American History, Vol. 91, No. 1 (Jun., 2004), 174-183.

38 Jacquelyn Dowd Hall, "The Long Civil Rights Movement and the Political Uses of the Past," The Journal of American History, Vol. 91, No. 4 (Mar., 2005), 1233-1263.
} 
year window in American history beginning with the Brown v. Board of Education case and ending with the Civil Rights Act of 1964 and the Voting Rights Act of 1965. "Then comes the decline:" rioting, militancy, the Vietnam War. ${ }^{39}$ Hall offers a narrative of the movement that is likely more familiar to professional historians: a "long" civil rights movement beginning with the New Deal and continuing well past the 1960s. What is most interesting about the article, however, is how Hall ties this memory to the counter-insurgent right, who found themselves on the wrong side of history in the decades following the "classical" era of the movement. What Hall demonstrates above all is that memory matters, and there is likely nowhere this is more obvious than in the present. How she does this is by connecting the past to politics, a move that only some historians of collective memory have begun to make.

\section{Memory in South Africa}

Much like the historiography of memory in the United States, South African historiography has been preoccupied with the question of white identity, particularly Afrikaner collective memory and identity. ${ }^{40}$ Following the end of Apartheid, the central question for historians of memory has been how Apartheid itself was remembered. The focus on Afrikaner memory at the expense of African memory has persisted, however. This is despite the fact that the Truth and

39 Ibid., 1235.

${ }^{40}$ See especially Leonard Thompson, The Political Mythology of Apartheid (New Haven: Yale University Press, 1985) and Vincent Crapanzano, Waiting: The Whites of South Africa (New York: HarperCollins, 1985), Ch. 3, "The Past," passim. 
Reconciliation Commission (TRC) brought to the public sphere the remembrances of many Africans of living under Apartheid. ${ }^{41}$

Easily the most powerful and likely the best known of these accounts is Antjie Krog's Country of My Skull. An Afrikaner herself, Krog attempts to reclaim the "best and proudest in the Afrikaner" and connects memory to identity in a very direct way. ${ }^{42}$ Krog covered the TRC for the South African Broadcasting Corporation (SABC), traveling from small town to small town and listening to the testimony of South Africans of all backgrounds and on all sides of the conflict. Krog offers an intensely personal account of the TRC, meditating on the way memory of Apartheid squares-or does not square-with her identity as an Afrikaner.

A useful contrast to the work on popular work on the TRC is one of the best collected volumes on memory in South Africa, Sarah Nuttall and Carli Coetzee's Negotiating the Past: The Making of Memory in South Africa. Nuttall and Coetzee

\footnotetext{
${ }^{41}$ On the TRC and memory, see Erik Doxtader, With Faith in the Works of Words: The Beginnings of Reconciliation in South Africa, 1985-1995 (East Lansing: Michigan State University Press, 2009) Antjie Krog, Country of My Skull: Guilt, Sorrow, and the Limits of Forgiveness in the New South Africa (New York: Three Rivers Press, 1998), and Priscilla B. Hayner, Unspeakable Truths: Confronting State Terror and Atrocity (New York: Routledge, 2002). On trauma, see Dominick LaCapra, Writing History, Writing Trauma (Baltimore: The Johns Hopkins University Press, 2001), Jeffrey C. Alexander, et al, Cultural Trauma and Collective Identity (Berkeley: University of California Press, 2004). On South Africa and the novelist J.M Coetzee, see Troy Urquhart, "Truth, Reconciliation, and the Restoration of the State: Coetzee's Waiting for the Barbarians," Twentieth-Century Literature Vol. 52, No. 1, Spring 2006, 1-21. On the phenomenon of "native nostalgia," where black South Africans recall the positives of life under Apartheid compared to the current neoliberal regime, see Jacob Dlamini, Native Nostalgia (Auckland Park: Jacana Media, 2009).

${ }^{42}$ Krog, 125.
} 
maintain the focus on the transformative effects of the transition to multiracial democracy. One notable exception to this is the article on the memory of Cape slavery by Kerry Ward and Nigel Worden. While Ward and Worden's article is not systematically comparative, the comparison the authors make with the United States also serves as a notable exception to the lack of comparative work on memory. Ward and Worden argue that the legacy of Cape slavery has been suppressed and forgotten, in large part due to the fact that Cape slavery was far removed from the system of Atlantic slavery as well as efforts by the Apartheid state to privilege white memory. Crucially, from the perspective of those involved in the anti-Apartheid struggle, unity was better achieved by claiming indigenous rather than slave ancestry. In the context of the Pan Africanist Congress (PAC) slogan of "One settler, one bullet," even imported slave ancestry was not useful for constructing solidarity. Better to claim indigenous Khoi and San ancestry, the ancestry of those who had been driven out by white colonialists. Much like Malcolm X, in 1989 colored PAC leader Benny Alexander changed his name to "!Khoisan X" to demonstrate how his name had been stolen by colonialism. The emphasis on the exceptional nature of memory in the Western Cape is noteworthy and should prompt scholars to think of how collective memory can vary regionally. 43

The same regional focus is the strong suit of the collected volume, Imagining the City: Memory and Cultures in Cape Town, and an approach enhanced by its focus

\footnotetext{
${ }^{43}$ Kerry Ward and Nigel Worden, "Commemorating, suppressing, and invoking Cape slavery," in Sarah Nuttall and Carli Coetzee, eds., Negotiating the past: The making of memory in South Africa (Cape Town: Oxford University Press, 1998).
} 
on the memory of ordinary, working people and their lives under Apartheid. At the level of the city, grand narratives about the Great Trek, for example, must compete with the memories of local events, remembered by local people. Despite the volume's theoretical sophistication, it does not take up the question of how local memory relates to national memory. Sofie Geschier offers an innovative study of the generational differences of memory of the forced removal of District Six. Another piece by Ncedisa Nkonyeni studies the rise of rap in Cape Town. Inevitably a comparative angle emerges, given the American origin of "gangsta" rap. Nkonyeni compares this with the rise of "nation conscious" rap in Cape Town. Apartheid censors were notoriously strict, but censors can only censor what they understand. As one of Nkonyeni's interviewees said of the politically turbulent 1980s, subversive music was not difficult to access or produce: "The hidden subversive element, the other, other levels of communication used.. coz they just thought it was niggermusic from the States." ${ }^{44}$ Nkonyeni's article is a useful reminder that music can be an important source of memory, and that comparative angles can emerge where they are least expected.

Like Nkonyeni, Annie Coombes sees political vitality in South Africa, despite many post-1994 disappointments. Coombes sees widespread discourse on issues of collective (or "public" in her terminology) memory as a sign of "the health and vitality of a political culture of critique and countercritique that was forged under

\footnotetext{
${ }^{44}$ Ncedisa Nkonyeni, "Da struggle continues into the $21^{\text {st }}$ century: two decades of nation-conscious rap in Cape Town" in Sean Field et al, Imagining the City: Memories and Cultures in Cape Town (Cape Town: HSRC Press, 2007), 158.
} 
the most difficult of circumstances and whose main protagonists have often paid dearly for their beliefs." ${ }^{45}$ Coombes' History after Apartheid: Visual Culture and Public Memory in a Democratic South Africa is a brilliant and foundational work, all the more so because its analysis of visual culture is so different from most other historians. Coombes' History after Apartheid demonstrates the difficulty of translating the experience of the Apartheid past into visual representation. Her attempts at bringing in visual culture from beyond the museum are laudable, and others would do well to follow this example. One example serves to illustrate this. In 1995, a new pornographic magazine did a photo shoot in front of the Voortrekker Monument. Instead of a simple transgression of the sacred/profane, Coombes argues quite persuasively that this was an act of dismantling the homogeneity of Afrikaner natonalism and ethnicity. The model was allegedly a direct descendant of a Voortrekker leader, and made an ironic comment about how 1995 could use such effective leaders as the Voortrekkers. This source may be exceptional, but it is indicative of the creativity that will be necessary to fully excavate attitudes toward the past.

Bill Nasson has written specifically on the legacy of the South African War in the context of post-Apartheid South Africa. Nasson notes that while some extremist Afrikaners were unhappy with Queen Elizabeth II's 1995 visit to South Africa, calling her the "great grand-daughter of a cruel Queen" (Victoria), he also stresses the

\footnotetext{
${ }^{45}$ Annie Coombes, History after Apartheid: Visual Culture and Public Memory in a Democratic South Africa (Duke: Duke University Press, 2003), 5.
} 
efforts made by many like the activist and later judge Albie Sachs to create a common memory of the similar experiences that both Afrikaner and black Africans suffered during the war. This was an effort within the ANC ranks that attempted to "go about transforming the meaning of the war, or how to imagine it anew, in a way that faced the future, not the past." Memory of the war was "cut...loose from its exclusivist association with conservative Afrikaner nationalist history." 46

The official nationalist history of the anti-Apartheid struggle, The Road to Democracy in South Africa, stresses that the ANC's "institutional commitment to non-violence was deep-seated and long-lasting" and that the sabotage campaigns of the early 1960s were not a significant challenge to this ethos, being only a "relatively muted and restrained form of armed struggle." 47 The volume does mention that for some in rural South Africa, "the socialisation of young men continued to emphasise the military arts, the formation of regiments and the defence of communities." This was a source for an "alternative political tradition that stretched back to independent kingdoms and wars of resistance." Some activists were taken with the Mau Mau revolt (an anticolonial struggle in Kenya against the British), and for some, events in South African and Eastern Africa merged. ${ }^{48}$ Beyond this brief mention, however, no specifics are given of the content of the collective memory tied to the

\footnotetext{
${ }^{46}$ Bill Nasson, "Anglo-Boer War in Post-Apartheid South Africa," Radical History Review, 78, 149-165. Also see Nasson, "The Unity Movement: Its Legacy in Historical Consciousness," Radical History Review 1990, 189-211.

47 The Road to Democracy in South Africa, Volume 1, 1960-1970, (Pretoria: Unisa Press, 2010), 53.

48 Ibid., 57-58.
} 
turn to armed struggle, or the tension between memories of violence versus nonviolence.

Leslie Witz is uniquely attuned to the contest, rather than construction of, over memory in Apartheid's Festival. While most of this work concerns itself with pro-Apartheid Afrikaner nationalism, one chapter breaks this mold. Focusing on the Garment Workers' Union in the fourteen years following the centennial of the Great Trek, Witz finds that some Afrikaners resisted the growing tide of nationalism and ethnic particularity. He concludes that efforts by Afrikaner nationalists to bring the garment workers into the Afrikaner nationalist fold and participate were an attempt to steer the workers away from the unionist Solly Sachs, who had racial attitudes the nationalists were less than receptive to. In this chapter Witz provides a case study of how labor and gender can factor into contests over memory, and raises the excellent question of just how powerful Afrikaner nationalism and its penetration of white social memory really was, even at its midcentury heights. ${ }^{49}$

Currently, Carolyn Hamilton's 1998 work, Terrific Majesty: The Powers of Shaka Zulu and the Limits of Historical Invention comes the closest to detailing the ways native South Africans contributed to memory in any period before 1994. As an anthropologist, Hamilton is less interested in the history of overt resistance than she is in representation, and traces the image of Shaka Zulu, the $19^{\text {th }}$ century Zulu king until the early 1990s. Indeed, Hamilton finds that the image of Shaka Zulu could be

${ }^{49}$ Leslie Witz, Apartheid's Festival: Contesting South Africa's National Pasts (Bloomington: Indiana University Press, 2003). 
used to both resist white supremacy—his anti-colonial legacy being rather obvious-but also to assert it, as Shepstone had used Shaka Zulu to promote indirect rule. At times, this was challenged-John Dube, for example, asked why Shaka's severity was so necessary for native administration, when the colonial authorities had themselves violently fought Shaka Zulu for that same severity. Hamilton acknowledges that there are limits to how Shaka Zulu could be used, and in fact finds his legacy (again) ambiguous. More importantly, she has shown that a project that recovers native South African memory from white colonial sources is not only important, but simply possible. ${ }^{50}$

The role of Shaka Zulu in the post-Apartheid context is only beginning to be studied. Hamilton has begun this, as have John and Jean Comaroff. The latter mention Shakaland, "an elaborate ethno-theme park and resort established on the site of a faux Zulu settlement," in their essay on the incorporation of identity and the commodification of culture as it relates to ethnicity. Further, "KwaZulu, the ethnonation itself, seems to be mutating slowly into a culture park, a tourist destination, the $u r$-space of tradition in the country at large." 51

${ }^{50}$ Carolyn Hamilton, Terrific Majesty: The Powers of Shaka Zulu and the Limits of Historical Invention (Cambridge: Harvard University Press, 1998).

${ }^{51}$ John and Jean Comaroff, Ethnicity Inc. (Chicago: University of Chicago Press, 2009), p. 11. On Zulu memory, also see Jeff Guy, Remembering the Rebellion: the Zulu Uprising of 1906 (Scottsdale, South Africa: University of KwaZulu-Natal Press, 2006). The memory of the Xhosa cattle-killing is ably captured by Andrew Offenburger, "The Xhosa Cattle-Killing Movement in History and Literature," History Compass, Vol. 6 Issue 7 (Nov. 2009), 1428-1443. 


\section{Anti-Apartheid Campaign}

Because this project consciously responds to recent work in the fields of comparative history and the history of collective memory, those fields have been the thrust of this historiographic review. How this project fits into discussions about the Black Power movement and the anti-Apartheid struggle also bear mentioning, however.

The history of the anti-Apartheid movement is enormous. On the South African side, a few key monographs stand out, particularly Tom Lodge's work, Black politics in South Africa since 1945 and Anthony Marx's Lessons of Struggle: South African Internal Opposition. ${ }^{52}$ Lodge's excellent chapter on "Guerrillas and insurrectionists" is long on detail of personalities, strategy, and politics, but short on ideology. No discussion of the symbols of MK or Poqo, the Pan African Congress oriented military group, is offered. Similarly, no mention is made of memory. Marx devotes little space to the sabotage campaign, but notes that "[b]y giving its army the same name that had earlier been used to refer to education as means of recapturing what had been lost in the battlefield, the ANC clearly signaled its shift

52 Tom Lodge, Black politics in South Africa since 1945 (London: Longmans, 1983), Anthony Marx, Lessons of Struggle: South African Internal Opposition, 1960-1990 (New York: Oxford University Press, 1992). 
from what Gramsci called a war of position to a war of maneuver."53 In other words, the ANC transitioned from an ideological war to a war of force. ${ }^{54}$

\section{Black Power}

In the United States, recent work on Black Power has usefully focused on the question of how Black Power operated at a local level. This stands in contrast to much work from the 1980s and 1990s, which tended to probe questions of culture and ideology more thoroughly. Among the best of the recent local studies of Black Power is Robert Self's American Babylon, which ties the histories of postwar suburbanization, racial segregation, and Black Power in Oakland, California together. ${ }^{55}$ Hasan Kwame Jeffries has situated the local effort to secure voting rights in Lowndes County, Alabama with Black Power and the rejection of non-violence, offering a picture of Black Power in the South. For these black southerners, gun

53 Marx, 38.

54 The existing literature on the anti-Apartheid campaign is vast. Along with Lodge and Marx, see especially Saul Dubow, The African National Congress (Stroud: Sutton Publishing, 2000), Julie Frederikse, The Unbreakable Thread: Non-Racialism in South Africa (Bloomington: Indiana University Press, 1990), Allister Haddon Sparks, Tomorrow is Another Country: The Inside Story of South Africa's Road to Change (New York: Hill and Wang, 1995), Padraig O'Malley, Shades of Difference: Mac Maharaj and the Struggle for South Africa (New York: Viking, 2007), David Everatt, The Origins of Non-Racialism: White Opposition to Apartheid in the 1950s (Johannesburg: Wits University Press, 2009), Raymond Suttner, The ANC Underground in South Africa to 1976 (Auckland Park, South Africa: Jacana Media, 2008), Thomas Karis, Gwendolen Margaret Carter and Gail Gerhart, From Protest to Challenge: A Documentary History of African Politics in South Africa, 1882-1990 (six volumes), and the South African Democracy Education Trust, The Road to Democracy in South Africa (four volumes, with two more forthcoming).

55 Robert 0. Self, American Babylon: Race and the Struggle for Postwar Oakland (Princeton: Princeton University Press, 2003). 
ownership was traditional and important to hunting small game. In the context of "midnight marauding" from police, non-violence was simply dangerous. Said one Lowndes County resident: “You can’t come here talking that non-violence shit. You'll get yourself killed, and other people too."56

Two very recent edited collections flesh out Black Power's manifold manifestations at the local level. David Goldberg and Trevor Griffey's Black Power at Work connects Black Power to labor issues from the Bay Area to Detroit to Newark. Judson L. Jeffries's collected volume examines the Black Panther Party in unlikely yet revealing locales, such as Houston, Kansas City, and Des Moines, Iowa. While these volumes have much to recommend them, they do little to explore the role memory of prior struggles played in the construction of post-civil rights Black Nationalist ideology..$^{57}$

Nearly two decades on, William Van Deburg's New Day in Babylon remains one of the most penetrating studies of Black Power. When discussing the ideology of Black Power, Van Deburg touched briefly on the question of history. African Americans on the radical left argued the previous three centuries of history could explain the current problems: "All felt they were reading history correctly by linking their cause to Third World liberation movements," Van Deburg observed. Further,

\footnotetext{
${ }^{56}$ Hasan Kwame Jeffries, Bloody Lowndes: Civil Rights and Black Power in Alabama's Black Belt (New York: New York University Press, 2009), 104.

57 David Goldberg and Trevor Griffey, eds., Black Power at Work: Community Control, Affirmative Action, and the Construction Industry (Ithaca: Cornell University Press, 2010; Judson L. Jeffries, ed., On the Ground: The Black Panther Party in Communities across America (Jackson: University Press of Mississippi).
} 
revolutionary nationalists argued that "the oppressed would have to defeat the monster with its own weapons," or in other words, with the use of force. ${ }^{58}$ Van Deburg does not elaborate or complicate his account of popular memory, but New Day in Babylon continues to serve as a useful departure point for beginning to understand the cultural and intellectual history of Black Power.

In sum, these overlapping historiographies have left several noticeable gaps. While collective memory has been usefully examined in many contexts, it is only beginning to be studied in the context of the anti-Apartheid and Black Power movements. This is true both of those scholars coming from the theoretical perspective of memory studies, or historians of the movements themselves. With the notable exception of McElya, on the subject of memory there has been little attention paid to how memory is gendered. ${ }^{59}$ Historians of comparative US-South African history have not engaged with collective memory either, a point raised by Alex Lichtenstein, who notes that "Comparative work on historical memory in the

\footnotetext{
58 William Van Deburg, New Day in Babylon: The Black Power Movement and American Culture, 1965-1975 (Chicago: The University of Chicago Press, 1992), 154155.

${ }^{59}$ A notable exception is Raymond Suttner's recent oral history work on the ANC underground, Raymond Suttner, The ANC Underground in South Africa (Johannesburg: Jacana Media, 2008), esp. Ch. 6, "Gendering the Underground."
} 
US South and South Africa remains to be done."60 Finally, there is no work on how memory contributes to race-making in either society. ${ }^{61}$

${ }^{60}$ Alex Lichtenstein, "Southern Identity: A Dissent," Safundi: The Journal of South African and American Studies, Vol. 9, No. 3, July 2008, 314.

61 This is in contrast to historians who have tied memory to identity. For more on race-making, see Marx, Making Race and Nation. 


\section{Mandela, MK and the Political Uses of the Past in South Africa}

Most histories of Umkhonto we Sizwe's sabotage campaign take pains to point out the day it began. For black and white South Africans alike, December 16, 1961 was not just any other day, but the $123^{\text {rd }}$ anniversary of the Battle of Blood River. In the history of Afrikaner nationalism, December 16 is easily the most significant day. It was a public holiday under Apartheid rule, and remains one today, though notably its name has changed to the "Day of Reconciliation."

The Battle of Blood River was fought in the context of the Great Trek, in which Afrikaners usually of Dutch or Huguenot descent left the British Cape Colony in the 1830s. The British had taken control around the time of the Napoleonic Wars and began instituting policies of racial liberalism such as the abolition of slavery and Ordinance 50, which allowed for a degree of racial equality. ${ }^{62}$ Another reason often cited is Afrikaners were tired of constant battles with neighboring Xhosa. Four thousand Afrikaners moved east and northeast toward Natal and the Transvaal, in the long run forming new Boer Republics like the Orange Free State.

In Natal, the voortrekkers, as they came to be known, encountered the Zulu kingdom, encounters which often led to war. The Zulu understood well that the

${ }^{62}$ For a good recent survey of these trends throughout the British Empire, see Christopher Brown, Moral Capital: Foundations of British Abolitionism (Chapel Hill: University of North Carolina Press, 2006). Brown situates the rise of British racial liberalism in the context of the aftermath of the American Revolution, arguing that the rhetoric of the American Revolution caused the British to take their claims to liberty seriously. Also see Timothy Keegan, Colonial South Africa and the Origins of the Racial Order (Charlottesville: University of Virginia Press, 1996), which as the title suggests, argues that the roots of the racial order lie in the $19^{\text {th }} \mathrm{C}$ British Cape. 
voortrekkers' presence was not in their best interest. In February of 1838, the Zulu king Dingane (Shaka's successor) and Piet Retief, widely considered the leader of the voortrekkers, signed a peace agreement. Shortly thereafter, Dingane and his warriors murdered Retief's party and nearly three hundred other whites and about two hundred of their Coloured "servants." The following December, Andres Pretorius led another campaign against the Zulu. The night of December 15, 1838, the commandos lashed their fifty-seven wagons together to form a laager. In the morning, a Zulu army of at least ten thousand descended on the laager. The aftermath saw around three thousand Zulu casualties, and not a single Afrikaner death. 63

Afrikaner collective memory highlights the vow—or, in Afrikaner political mythology, the Covenant—-that the commandos took before the battle. If God granted a victory over the Zulu, the Afrikaners pledged to construct a church and always commemorate the anniversary of the battle. At least, this was how Afrikaners during the Apartheid era remembered the battle. Leonard Thompson has reexamined the sources and found that "nearly all the members of the commando proceeded to forget all about any such vow or covenant." 64 Rather, the story of the vow or covenant was tweaked and embellished to suit the political needs of the day.

${ }^{63}$ For a thorough reexamination of the sources, see Leonard Thompson, The Political Mythology of Apartheid (New Haven: Yale University Press, 1985), 151. 64 Ibid., 146 
Umkhonto we Sizwe chairman Nelson Mandela was all too aware of this Afrikaner nationalist context as he made the "fateful step" of abandoning nonviolence. The more immediate historical context for the ANC was precisely this nonviolent tradition, influenced by British liberalism, Christianity, and Gandhian satyagraha. The latter, pioneered by Gandhi on behalf of the rights of South African Indians in 1906, translates roughly as "holding onto truth" and was obstinately nonviolent. Mandela describes this principle as so firmly ingrained into the ANC that it was "beyond question or debate." In his autobiography, Mandela presents MK as a break from this tradition. Abandoning nonviolence meant that MK was "embarking on a new and more dangerous path, a path of organized violence, the results of which we did not and could not know."65

While it is generally held that this was a break for the ANC, Mandela later recalled in an interview that as early as $1953^{66}$ he asked fellow ANC member Walter Sisulu to inquire about procuring arms while Sisulu was in China. While Mandela's view at the time was unpopular, he "remained convinced that this was the correct strategy for us." 67 Indeed, by looking to the past as a guide, Mandela helped connect MK to a history of violent resistance stretching back much farther than the half

65 Mandela, Long Walk to Freedom, 274.

${ }^{66}$ Although in Mandela's autobiography, the first discussion of armed struggle is dated as 1952.

${ }^{67}$ Nelson Mandela, Conversations with Myself (New York: Farrar, Straus and Giroux, 2010), 74 . 
century long existence of the ANC. In this view, the nonviolent era is the interregnum.

It was in the context of the stay at home strikes of 1960 organized by the ANC's chief rival, the Pan Africanist Congress (PAC) that Mandela began seriously discussing the possibility of armed struggle in a Soweto safehouse, as there was a warrant out for Mandela's arrest. The state's reaction to the stay-at-home strike shocked Mandela, although the reaction of the populace was disappointing. Fortyeight hours before the strike was planned, "the government staged the greatest peacetime show of force in South African history." The situation was growing to be historically exceptional in Mandela's view, a break with the past. Certainly the tense and frightening language he uses reinforces this reading: "While Saracen tanks rumbled through the dirt streets of the townships, helicopters hovered above, swooping down to break up any gathering. At night, the helicopters trained searchlights on houses." ${ }^{68}$ At the same time, Mandela and others perceived vulnerabilities in the Apartheid state that they hoped to exploit, as Tom Lodge has stressed. Authorities had temporarily suspended the pass laws in response to protests, and shaky international investor confidence caused a slump in the South African economy, while many whites began to emigrate. ${ }^{69}$

Even at the stage of the strike, dates mattered. May 31, 1961 was the first Republic Day in South Africa, and also the anniversary of the end of the South

68 Mandela, Long Walk to Freedom, 269.

${ }^{69}$ Lodge, Mandela, 88-89. 
African War (also known as the Boer War, which pitted the Afrikaners against the British). On this day in 1961 South Africa became a republic. Not coincidentally, it was the third day of the stay-at-home strike. Despite the failure of the strike, Mandela noted gleefully that, "The white celebration of Republic Day was drowned out by our protest."70 While the Afrikaners lost the South African War and the independent Afrikaner republics were incorporated into the British Commonwealth in 1902, the memory of defeat was cultivated by Afrikaner nationalists in the decades following. To time a strike to coincide with Republic Day and the conclusion of the South African War was surely a deliberate insult to the Afrikaner nationalists. ${ }^{71}$

When Mandela first officially broached the subject of violence in June of 1961, Moses Kotane, the secretary of the Communist Party as well as an ANC executive, quickly rebuked him at the meeting. Walter Sisulu, the former head of the ANC, arranged for a private meeting between the two men. In his argument, Mandela relied on both colonial African and recent Cuban history. The first was with his use of an "old African expression: Sebatana ha se bokwe ka diatla (The attacks of the

${ }^{70}$ Mandela, Long Walk to Freedom, 270.

${ }^{71}$ Although as Anthony Sampson notes, the sabotage timing was embarrassing in that it came only six days after Albert Luthuli was awarded the Nobel Peace Prize. Anthony Sampson, Mandela: The Authorized Biography (New York: Alfred A. Knopf, 1999), 157. 
wild beast cannot be averted with only our bare hands.)" Mandela could have used any stock phrase, but chose to speak in Xhosa, the language of his ancestors. ${ }^{72}$

Tellingly, however, he also compared the South African situation to that of recent Cuban history. Appealing to Kotane's Communist loyalties, Mandela told him "that his opposition was like the Communist Party in Cuba under Batista." It was impossible to wait for textbook perfect conditions, so like Fidel Castro, the ANC needed to act. ${ }^{73}$

Once it had been decided that MK would split from the ANC, Mandela set out to discover "the fundamental principles for starting a revolution." His choice of reading tended to be leftist, but not exclusively. Cuban history and Mao Tse-tung were on the syllabus, but also histories of guerrilla warfare from Israel, Ethiopia, Kenya and other African states.

In the interim between the founding of MK and the first bombings, Mandela chose June 26, 1961 to release a public statement calling for a constitutional convention. If the state did not meet to convene one, noncooperation would continue. This was another example of Mandela choosing an anniversary to make a public move. June 26 was Freedom Day, the anniversary of the start of the 1952 defiance campaign waged by the ANC in cooperation with the South African Indian Conference (SAIC) and three years later, the day the ANC adopted the Freedom

\footnotetext{
72 Mandela, 271.

${ }^{73}$ Ibid., 271.
} 
Charter. The 1952 and 1955 events were both key developments in the development of nonviolent ANC action against Apartheid, itself just a few years old at this point, having just been born in 1948. The Group Areas Act was passed in 1950, solidifying Apartheid in urban areas. Mandela's statement had hints of what was in store later that year: "Only through hardship, sacrifice and militant action can freedom be won." ${ }^{74}$

One major issue with reading Long Walk to Freedom as a guide to the 1960s, however, is the post-Apartheid context of reconciliation in which it was published. While famously Mandela wrote much of it while imprisoned on Robben Island, clearly changes were made for its publication in 1994. As Mandela tells the story, even in 1961 he was thinking about the endgame for Apartheid, a process for which he became even better known for three decades later. For Mandela, the key analogue to reconciliation was obvious: the South African War. Fifty years on, friction "between Afrikaner and Englishman was still sharp." This animosity was an outcome Mandela desperately hoped to avoid if one believes his autobiography. Mandela's fine logic is likely the best evidence of this. The cloud of the South African War still hung over South Africa, and Mandela correctly wondered "what would race relations looks like between white and black if we provoked a civil war?" To that end, sabotage, rather than open revolution or terrorism, was the order of the day for

${ }^{74}$ Ibid., 276. 
MK. "Strict instructions were given to members of MK that we would countenance no loss of life."75

The first bombings of electric stations and government offices in Durban, Johannesburg and Port Elizabeth took place on December 16, 1961. Mandela points out that "We chose December 16, Dingane's Day, for a reason." Dingane's Day is what the Day of the Vow-referring to the vow taken by the voortrekkers before the Battle of Blood River-was previously known as. Choosing the anniversary of an African defeat might seem out of place, but the symbolism was powerful. For one, the religious and nationalistic overtones attached to that day for Afrikaners was tremendous, and the fact MK choose this date can only be seen as an affront. And despite the Zulu defeat, December 16 marked an effort to reconnect with a powerful state that was widely feared by both Europeans and other African states in the early nineteenth century. As Mandela stresses in an effort to claim affinity, Dingane was the half brother of Shaka, the most brutal and most widely known Zulu leader who preceded Dingane. That Dingane assassinated his half-brother to claim the Zulu throne was likely not a subject Mandela or MK members wanted to broach, and he makes no mention of in his autobiography. In Mandela's telling, Shaka "ruled the most powerful African state that ever existed south of the Limpopo River." The past, for Mandela, was truly present: "We chose December 16 to show that the African had only begun to fight, and that we had righteousness-and dynamite-on our

75 Mandela, Long Walk to Freedom, 283. 
side."76 If Afrikaners could claim the moral high ground from their defeat in the South African War, so too could South Africans from the Battle of Blood River. Simply by choice of date, MK resurrected a war that was nearly a century and a half over.

Mandela's powerful imagery notwithstanding, tensions existed in the collective memory of MK members. On the surface, Mandela's Xhosa ancestry would seem to be in conflict with the Zulu kingdom that Shaka ruled. Indeed, Zulu-Xhosa history is one of conflict. Many of the pressures endured by the Xhosa in the 1840s and 1850s, culminating in the cattle-killing of 1857 that removed their material support, could be traced to their displacement in the Mfecane, which featured Shaka Zulu as one of the Xhosa's antagonists. ${ }^{77}$ The ANC's steadfast commitment to nonracialism helps explain the ambiguity in memory, but there were other reasons. Unlike the ANC, MK allowed those of European descent whom they trusted to join, many of whom had combat or guerrilla warfare experience. One of them, Ronnie Kasrils, had a very different outlook on the past. Kasrils became known as the Red Pimpernel, much like Mandela came to be known as the Black Pimpernel—both names a nod to the French Revolution. Disgust with the pervasive racism in South

76 Mandela, Long Walk to Freedom, 285.

${ }^{77}$ For a good overview of the Mfecane, see Carolyn Hamilton, ed., The Mfecane Aftermath: Reconstructive Debates in Southern African History (Johannesburg: Witswatersrand University Press, 1995), the product of a 1991 conference which responded to Julian Cobbing's controversial 1988 article, "The Mfecane as Alibi: Thoughts on Dithakong and Mbolompo," The Journal of African History, Vol. 29, No. 3 (1988), 487-519. On the 1856-7 Xhosa cattle-killing, see J.B. Pieres, The Dead Will Arise: Nongqawuse and the Great Xhosa Cattle-Killing Movement of 1856-7 (Bloomington: Indiana University Press, 1989). 
Africa had led Kasrils to join the Communist Party. He did not believe there was such a thing as colorblind capitalism. Like most other SACP members, Kasrils hoped for a two stage revolution: the first led by the ANC, and the second setting the stage for a socialist future.

In the view of Kasrils' and other communists' account of history, the revolutionary impulse was centered in Moscow, far away from Blood River. The October Revolution of 1917 had "inspired the formation of communist parties throughout the world." Further, the Soviets had defeated Hitler in the Second World War and had "transformed a backward Czarist Empire occupying one-sixth of the world's land surface." It was the early history of the Soviet Union that Kasrils and his comrades looked toward. "Even the exposure of Stalin's crimes by Khrushchev in 1956 failed to shake the basic ideological position of the old guard," he noted in his 1993 autobiography. ${ }^{78}$

In the immediate aftermath of the first sabotage campaign, Kasrils got involved in a debate with Rowley Arenstein, a lawyer and radical from Durban. As Kasrils defended the sabotage campaign as a move against the demoralizing campaign of nonviolence, the two men engaged in a debate over the history and theory of communist revolution. Arenstein began, "The people! That's just the problem. We fail to organise the masses, so we turn to using firecrackers. A group of conspirators will not give us the solution. Read Lenin on Blanqui. He gives a searing

\footnotetext{
${ }^{78}$ Ronnie Kasrils, 'Armed and Dangerous': My Undercover Struggle Against Apartheid (London: Heinemann, 1993), 37.
} 
indictment of exactly this type of deviation." Unlike Karl Marx, Louis Blanqui believed a small group could usher in the socialist revolution rather than the working class as a whole. In effect, Arenstein had waded into debates from nineteenth century Europe. But like Mandela, Kasrils used the counterexample of Fidel Castro and the Cuban Revolution from two years previous to demonstrate that it was indeed possible for a small group to successfully foment a revolution. Castro and Che, as we will see below, was a source common to both MK and the Black Power movement during the 1960s.

In a unique twist, Kasrils published poetry in the African Communist under the pseudonym of ANC Khumalo while in exile following the Rivonia trial. This poetry tended to celebrate the anticolonial struggles of the South African past, such as the Battle of Isandhlwana in 1879 or the Bambatha Rebellion of 1906, both of which pitted Zulu against the British Empire. One example from the official ANC journal, Sechaba, in 1979-the "Year of Moshoeshoe" according to the magazine-is illustrative. The purported author, Vulanyana Sono, may or not be Kasrils, but certainly the themes of the past, nature, and struggle are consistent. In the poem "Isandhlwana" Sono referred to "plumed warriors...waiting waiting waiting...a singing clash of spears." Isandhlwana was a name that "never lost its sting."79 Likely Kasrils was influenced by the growing tide of anticolonial struggle throughout Africa, if not in South Africa at the time.

79 Vulanyana Sono, “Isandhlwana," Sechaba, May, 1979, 32. 
Banned and underground as they were, it was not until the MK leaders were caught by the police that they truly managed to get their voices heard, in what became known as the Rivonia trials of 1964. As Hilda Bernstein recounted, "The Rivonia Trial became the platform from which, for the first time, the black-out of state censorship and of press self-censorship was broken." 80 The trial testimony thus presents a perfect opportunity to understand the use of collective memory in the planning of MK.

Govan Mbeki recalled during testimony that Arthur Goldreich had been brought in to deliver lectures, which Mbeki assisted in producing. Goldreich's chief goal was to teach military skills, as black South Africans were barred from the South African Defence Force. Goldreich also delivered "a historical background...the history of M.K., why it was necessary to embark on sabotage."81

Bruno Mtolo—one of the most damaging witnesses for the prosecution-was more descriptive about the content of the history Mandela instructed the MK members to learn. ${ }^{82}$ Mtolo was contemptuous of what he saw as the corrupt leadership of MK, though he respected Mandela. Mandela himself was "bewildered by Mtolo's betrayal," and noted that while he suspected some MK members might

${ }^{80}$ Hilda Bernstein, The World That Was Ours: The Story of the Rivonia Trial (London: SAWriters, 1989), ix. Bernstein was married to Lionel Bernstein, one of the white Rivonia defendants.

81 The State v. Nelson Mandela and Others: extract of evidence from Govan Archibald Mbeki, Vol. 28., 94.

82 Tom Lodge, Mandela: A Critical Life (Oxford: Oxford University Press, 2006), 110111. 
break under torture, even that had not been required for Mtolo to "embellish his evidence." ${ }^{83}$ Two years following the trial, Mtolo published his account of MK and the Rivonia trial. Mtolo begins the book by explaining that Bruno Mtolo is not his real name-he needed to change it because the Xhosa members of the ANC could not pronounce his Zulu name correctly. Fitting with his low opinion of MK, he finishes the book by calling on the ANC leader Albert Luthuli to embrace "separate development," and asks for the Zulu and "Afrikaans people" to finally make peace. ${ }^{84}$ Like Mandela, Mtolo connected MK to the precolonial past. Besides connecting the struggle to Cuba, China, and Vietnam, Mtolo and others were instructed "to learn our real history of South Africa." This was personal, as suggested by Mtolo's sense of ownership, but also a public duty that Mtolo felt needed to be widely publicized. "We must particularly study our own history, because we must show the people that this is not the present struggle only, the struggle has not just started now, it is a struggle that has been coming on since dates we can mention, for instance times of Dingaan, times of Shaka, and so on." In the same breath, Mtolo describes how difficult it would be to convert the rural Africans to the MK's cause. Thus, the claim made to the rural African past conjured by Shaka and the Zulu may have been a strategic effort to reach rural Africans. ${ }^{85}$

83 Mandela, Long Walk to Freedom, 357-8.

${ }^{84}$ Bruno Mtolo, Umkhonto we Sizwe: The Road to the Left (Durban: Drakensberg Press, 1966), 194-195.

85 The State v. Nelson Mandela and Others: extract of evidence from Bruno Mtolo, Vol. 15. 
Indeed beyond rural South Africans, the ANC was publishing material that circulated throughout southern Africa more broadly. One pamphlet published just weeks before the Rivonia trial in newly independent Dar es Salaam, Tanzania, contained a short history of southern Africa and the ANC's place within it. The pamphlet listed four reasons that South Africans were defeated by foreigners: lack of weapons; a lack of unity among the "African people"; South Africans fought the invaders at different times and never mounted a concerted attack; and finally, "Because of some petty family and selfish quarrels some of the tribes allied themselves with the invaders against their own people!"86 This past was applicable to the present and future, as these were lessons that "all future leaders of the liberation struggle must learn." In a clever twist, this violent past was ascribed to the memory of whites. While Africans might remember these struggles as defeats, white South Africans "fear us because they know from bitter experience what we are capable of, because they know what formidable force we are." In this view, importance of the colonial past was vindicated by the judgment of whites. While Mandela looked to the South African War to underscore the bitter feelings it left behind, this pamphlet used it to underscore the importance of unity, which the English and Afrikaner had gained in the war's aftermath and turned to the dispossession of native Africans. ${ }^{87}$ The importance of unity was surely a rebuke to the ANC's rival, the PAC-another contemporaneous pamphlet had the telling title,

86 "African National Congress of South Africa", pamphlet, Dar es Salaam, July 11, 1963, 4.

${ }^{87}$ ANC, 6. 
“The ANC Spearheads Revolution—Leballo? No!”, referring to PAC leader Potlako Leballo. 88

In the context of the pamphlet campaign, it was Nelson Mandela's statement to the court that despite being delivered in a monotone voice over many hours spoke the loudest and carried the farthest. Mandela began by setting the record straight and pointing out that the present struggle was indigenous in origin and not the product of outside interference, stirred up by communists or anyone else. Rather, it was done because of his experiences in South Africa and his "proudly-felt African background."89

Mandela appeared in court on the first day of the trial wearing a leopard skin kaross (cloak), an indication of his Xhosa royal status. Mandela's wife Winnie was similarly dressed in a "beaded headdress and ankle-length Xhosa skirt." A praise singer was present outside the courtroom, singing Mandela's family tree..$^{90}$ This suggests the ways that the memory circulating around MK could not only be captured in language, but also embodied. Mandela was known to be sharp dresser in the Western style, and assuming the clothing of his ancestors was an important break for him. Indeed, the symbolic element did not go unnoticed by the court, which attempted to confiscate the kaross. The symbolism may have been an attempt

88 “The ANC Spearheads Revolution—Leballo? No!", leaflet, May 1963.

${ }^{89}$ Mandela, Long Walk to Freedom.

90 Tom Lodge, Mandela: A Critical Life (Oxford: Oxford University Press, 2006), 104. 
to gain support from the Pan Africanist Congress (PAC), or at least placate the "Africanist" stream that still remained in the ANC.

When Mandela was growing up in the Transkei in the 1920s the region was still able to support a peasant economy. ${ }^{91}$ While there were hints of white influence such as automobiles, Mandela's early life was relatively insulated from European domination. It was in this context that he could recall at Rivonia that as a youth he "listened to the elders of my tribe telling stories of the old days." The ANC especially played up Mandela's claim to royal Xhosa ancestry, but the stories Mandela learned did not discriminate between Xhosa or Zulu. As Mandela told the court, "Amongst the tales they related to me were those of wars fought by our ancestors in defence of the fatherland. The names of Dingane and Bambata, Hintsa and Makana, Squngthi and Dalasile, Moshoeshoe and Sekhukhuni, were praised as the glory of the entire African nation." The diverse names mentioned refer to a wide variety of leaders who fought against Afrikaners, the British, and other African states. The inclusion of Moshoeshoe is telling. While Moshoeshoe was no stranger to war, he is often noted for his diplomatic and peaceful methods, a figure that might have been especially appealing to Mandela, and perhaps the judge. At trial, Mandela also left out Shaka from his list of "ancestors," no doubt because Shaka's ferocity would not go over well with the judge or the white public that would hear his remarks. ${ }^{92}$

\footnotetext{
91 Ibid., 2.

92 Nelson R. Mandela's statement to the court during the Rivonia trial, April 20, 1964.
} 
The violent history of white supremacy also featured in Mandela's statement, echoing the theme of loss he described in Long Walk to Freedom with regard to the Battle of Blood River. Mandela recalled the massacres perpetrated by the state over the preceding decades, asking, "How many more Sharpevilles would there be in the history of our country?" Again Mandela looked to the past to explain his strategic decision, and not just the turn to violence. In 1964 Mandela was already looking decades ahead to the eventual transition to multiracial democracy. He asked rhetorically, if there were more Sharpevilles, "how could Black and White ever live together again in peace and harmony?" The only solution to the issue, Mandela argued, was violence in defense against violence: "it was precisely because the soil of South Africa is already drenched with the blood of innocent Africans that we felt it our duty to make preparations as a long-term undertaking to use force in order to defend ourselves against force." 93

The collective memory deployed by the MK in the Rivonia Trial stands in contrast to that used by ANC President Oliver Tambo only a few years later on Freedom Day, 1967. Tambo celebrated June 26 by recalling the noncooperation movements of the 1950s. By not showing up to work, Africans broke the law to "honour the victims of decades of white violence and massacres and to assert their resolve to pursue the struggle for freedom despite brutal repression." No mention was made of the centuries-long struggle against white domination that Mandela made. For Tambo, the struggle was measured only in decades. No mention was

${ }^{93}$ Nelson R. Mandela's statement to the court during the Rivonia trial, April 20, 1964. 
made of MK's daring if unsuccessful attack on the Apartheid state, nor the glories of old African states. Indeed, the 1952 noncooperation campaign stood for Tambo as "the finest hour in the development of national political awareness among our people." June 26 contained "a shining thread which speaks of a determination to win, a dedication to a national cause and to the principle of unity among the ranks of the oppressed." December 16, wars against settler colonists, or even the campaigns of MK and Poqo had no place in official ANC memory. Following the Rivonia arrests, Tambo had to balance the interests and morale of the MK cadres and ANC exiles abroad while also attracting interest and support from civil society in the West. ${ }^{94}$

In the history evoked by Tambo there was an alarming amount of violence directed at Africans. Tambo reeled off the names and figures of many: the 1919 AntiPass Campaign, the 1921 Bulhoek massacre, the 1922 Bondelswarts massacre, the Durban beer boycott killings in 1929, and continued on until he reached the death of 18 Africans during the May Day demonstrations in 1950. Where Mandela had argued that the defeat at Blood River was merely the starting point, Tambo offered no such reasoning.

Perhaps because of his status as an exile in London, tasked with building international solidarity for the anti-apartheid struggle, Tambo looked to the rest of the world for inspiration and solidarity rather than the South African past. As he noted, "June 26 has grown into an international day of solidarity with the cause of

${ }^{94}$ Luli Callinicos, Oliver Tambo: Beyond the Engeli Mountains (Claremont, South Africa: David Philip, 2004), 301. 
the oppressed people of South Africa" and observed throughout "South Africa, Asia and Latin America." Closer to home, the "African revolution has rolled down to South Africa's doorstep"-Apartheid's allies were under pressure in Angola, Rhodesia (now Zimbabwe) and South West Africa (now Namibia). If there was a place for the contemporary anti-colonial struggle to symbolically appropriate the anti-colonial struggles of the nineteenth century, this would have been a good moment, and yet Tambo made no mention of this past. One explanation might be that it was still too closely tied to the sabotage campaigns of MK and Poqo, which had been swiftly repressed by the Apartheid state. ${ }^{95}$ With the growing number of ANC exiles abroad in Southern Africa, the USSR, London, and elsewhere, and the increased possibility of support from the West for boycotts and sanctions, invoking colonial warrior heroes was not the best strategy by 1965 .

Clearly memory was an important theme in the MK's sabotage campaign and in the resulting trial. This much it has in common with the Black Power movement in the United States. More notable is the content and character of the memory that existed in the minds of the protagonists. Black South Africans like Mandela placed themselves along a line of descent reaching back to Dingane, Shaka, and Moshoeshoe regardless of their actual ancestry. This is a clear reflection of the

\footnotetext{
95 Oliver Tambo, "A call to all revolutionary forces to rally behind the struggle against Fascist Tyranny in South Africa" Sechaba, June 26, 1967. For more on the argument that South Africa and the rest of southern Africa were both dominated by Europeans using similar mechanisms, see Mahmood Mamdani, Citizen and Subject: Contemporary Africa and the Legacy of Late Colonialism (Princeton: Princeton University Press, 1996).
} 
ANC's universalist ethos. The greatest divergence from the collective memory as constructed by anti-apartheid fighters and that developed by Black Power advocates in the United States was the focus on reconciliation, associated most prominently with Mandela himself. The relation between memory and reconciliation has been noted in many other contexts, and in and of itself is not surprising. ${ }^{96}$ What is striking is that despite the brutal repression MK, the ANC and other groups in South Africa faced, the endgame of Apartheid was already being planned for on the basis of a bloody past that needed to be prevented from reoccurring at any cost. Indeed, the armed struggle against Apartheid did not officially end until 1990, but an integralalbeit contested-component of the ANC's blueprint for the intervening twenty-six years can be seen in the memory work circulating around MK.

In the power vacuum that followed the imprisonment of most of the MK members on Robben Island came Black Consciousness. Daniel Magaziner has recently argued that Black Consciousness (BC) "bridged the 1960s quiet and 1970s events in a way that no movement could." ${ }^{97}$ Magaziner argues that at the end of the 1960s, an increasingly moral and religious opposition to Apartheid began, and by the mid-1970s, "political rhetoric had assumed a Christian aura, and Christ had in turn been incarnated in the cauldron of South African politics." ${ }^{18}$ Indeed,

\footnotetext{
${ }^{96}$ See for example Antonia Chayes and Martha Minow, eds., Imagine Coexistence: Restoring Humanity After Violent Ethnic Conflict (San Francisco: Wiley Bass, 2003). 97 Daniel Magaziner, The Law and the Prophets: Black Consciousness in South Africa, 1968-1977 (Athens: Ohio University Press, 2010), 6. 98 Magaziner, 58.
} 
Christianity had been an important influence on the ANC before and during the MK's sabotage campaign. The leader of the ANC at the time, Albert Luthuli, was a Christian Zulu. In this sense, MK represented a break from the thread of Christianity that runs through the liberation struggle, from Luthuli to Robert Sobukwe, Steve Biko, and Desmond Tutu. ${ }^{99}$

Steve Biko was the most influential BC thinker, but "not a well-known Christian." However, Magaziner argues that the Biko-led South African Students' Organization (SASO) "cultivated...religiosity from the beginning." 100 While it is not entirely absent, Biko did not play up religion in most of his writing, nor did memory play a central role. Biko's vision of the past was very different from Mandela's, largely owing to their radically different upbringings. Biko himself noted that he had "lived all my conscious life in the framework of institutionalised separate development." While Mandela grew up hearing stories of the glory of his ancestors, Biko writes as though he has little sense of African history. While he believed the past to be important to $\mathrm{BC}$, he said "only scant reference is made to African heroes." Again, in contrast to Mandela, Biko offers no specifics of the kind of heroes he would like to revive. ${ }^{101}$

\footnotetext{
${ }^{99}$ See Lyn S. Graybill, Religion and Resistance Politics in South Africa (Ann Arbor: University of Michigan Press, 1995) and Richard Elphick and Rodney Davenport, Christianity in South Africa: A Political, Social, and Cultural History (Berkeley: University of California Press, 1997).

100 Magaziner, 124.

101 Steve Biko, "We Blacks," I Write What I Like (Chicago: University of Chicago Press, 1987), 27-29.
} 
In contrast to $\mathrm{BC}$ and the $\mathrm{ANC}$, the collective memory evoked by Mandela and others involved in MK stands out for its insistence on the importance of an indigenous past to the contemporary struggle. In particular, connecting the contemporary turn to violence with the violent colonial and pre-colonial wars was a powerful rhetorical move. 


\section{Black Power and the Political Uses of the Past in the United States}

While the Black Power movement always contained multiple, overlapping streams of thought and action, the difference between it and the preceding Civil Rights Era seems clear. In 1970, the difference was clear enough that the historian Eugene Genovese could remark that the movement of 1954-1964 which focused on legalistic aims and nonviolent methods "after only a few years already seems like some distant Golden Age."102

The collective memory in which Black Power activists grounded their actions did not emerge out of thin air, however. Even before 1965, African Americans committed to ending segregation, poverty and violence against blacks articulated a memory that emphasized the Civil War and Reconstruction, and also the racialized violence that would only end, in the view of some, by more violence. While he advocated a legalist agenda, C. Vann Woodward's 1955 study, The Strange Career of Jim Crow is one of the best precedents for grounding present struggles in a particular reading of the past. Although written by a professional historian, the study was highly motivated by the contemporary struggles to end racial segregation and was widely read beyond the academy. Woodward attempted to demonstrate

\footnotetext{
102 Eugene Genovese, "The Influence of the Black Power Movement on Historical Scholarship: Reflections of a White Historian” Daedalus, 1, Spring, 1970, 474.
} 
that segregation had not always existed in the American South but in fact was only a recent invention. ${ }^{103}$

Others saw the doctrine of non-violence as a recent development. While many activists in the SCLC and other groups traced their nonviolent lineage back to Henry David Thoreau's insistence that the abolitionists rely only on civil disobedience or William Lloyd Garrison's demands for immediate emancipation, Robert F. Williams did not see things that way. Timothy Tyson has written a useful study of Williams, the head of the Monroe, North Carolina branch of the National Association for the Advancement of Colored People (NAACP). Tyson argues for continuity between Williams' organizing efforts and the black militancy movement, noting how influential he was on the Black Panther Party for Self-Defense. ${ }^{104}$ Williams himself published Negroes with Guns in 1962, well ahead of the end of the "Golden Age" and drew on memory for his arguments for armed self-defense. 105

Much like the founders of MK, Williams argued that racialized violence perpetrated against blacks could only be defended against by further defensive violence. During an attempt to desegregate a local swimming pool in Union County, Williams and the NAACP ran up against Ku Klux Klan resistance. The Klan

\footnotetext{
103 Woodward was also involved similar research for the Supreme Court's Brown v. Board of Ed. decision. See James T. Patterson, Brown v. Board of Education: A Civil Rights Milestone and Its Troubled Legacy (New York: Oxford University Press, 2001), 39-40.

104 Timothy B. Tyson, Radio Free Dixie: Robert F. Williams and the Roots of Black Power (Chapel Hill: University of North Carolina Press, 1997), 300.

105 Robert F. Williams, Negroes with Guns (New York: Marzani and Munsell, 1962).
} 
threatened to drive Williams and the NAACP out of the county. The local police refused to protect them, and the FBI insisted it was a local matter. Williams explained what was for him the only reasonable response: "Since the city officials wouldn't stop the Klan, we decided to stop the Klan ourselves." ${ }^{106}$ Self-defense was necessary for a number of reasons according to Williams, one of which dated back to 1868: "We started this action out of the need for defense, because law and order had completely vanished; because there was no such thing as a $14^{\text {th }}$ Amendment to the United States Constitution in Monroe, N.C."107

Of course, the Fourteenth Amendment was still very much on the books all over the United States in 1962, although clearly the practical effect of this was limited. But Williams could have chosen to lay claim to any number of other constitutional amendments, or indeed many more philosophical reasons that the treatment of the NAACP was unwarranted. That he chose the Fourteenth is significant, and foreshadowed the way others would use the memory of emancipation and Reconstruction to situate their activism. Passed in 1868, the Fourteenth Amendment was a crucial plank in the efforts of Radical Republicans to secure rights for the freedmen of the American South. The Amendment nullified the infamous Dred Scott v. Sandford case of 1857 that ruled blacks were ineligible to be United States citizens. To claim that the Fourteenth Amendment was not honored in Union County meant that in effect the efforts to secure that amendment were for

\footnotetext{
106 Williams, 54.

107 Ibid., 54.
} 
naught, and that the Civil War, emancipation and Reconstruction had all been negated by local whites.

Indeed Williams devoted a whole chapter of his book to the theme of selfdefense as an American tradition. Williams' reading of American history-and it was very US-centric-focused on the way "progress" was ever only attained through "violence and upheaval." This was a principle that "began at Lexington and Concord" - a reference to the American Revolution beginning in 1775.108 Just as Stokely Carmichael and Malcolm X would argue a few years later, Williams rejected the pleas of well meaning white liberals who "preach a special doctrine [of nonviolence] to Negroes." Williams compared this attempt at liberal evangelization to the evangelization of slaves centuries previously. "Instead of the doctrines which produced the rugged aggressively independent and justice seeking spirit that we associate with Colonial America as the New England Conscience, the slaves were indoctrinated in the most submissive 'trust-your-master' pie-in-the-sky after-youdie Christianity."109 Though it was revealing of Williams' view of white attitudes, in fact Williams did not see either form of evangelization as very effective; slaves and midcentury African Americans continued to rebel. "As far back as the $16^{\text {th }}$ century, and the beginning of the $17^{\text {th }}$ century, Negroes were even rebelling on the slave ships. The history of American Negro slavery was marked by very many

\footnotetext{
108 Williams, 110.

109 Ibid.,113.
} 
conspiracies and revolts on the part of the Negroes," he proclaimed. ${ }^{110}$ The past was used effectively to show that blacks did not require an ideology to demand, or simply take, their freedom.

Williams' views on violence were a direct criticism of the dominant groups in the civil rights movement, particularly the Southern Christian Leadership Conference (SCLC, led by Martin Luther King Jr.), the Student Nonviolent Coordinating Committee (SNCC) and the Congress of Racial Equality (CORE). However, events soon caught up with Williams' prognostications. SNCC members like Stokely Carmichael began arming themselves for self-defense, and soon Carmichael and others like Malcolm X and Huey Newton began to challenge the nonviolent ethos.

Writing on the heels of Martin Luther King Jr.'s Where Do We Go From Here?, which advocated a far more robust civil disobedience campaign than they had previously pursued in Montgomery, among other places, Stokely Carmichael and Charles V. Hamilton turned "at least a generation of reputable social science scholarship on its head" with the publication of Black Power in 1967.111 Rejecting the view predicted by Gunnar Myrdal is his classic 1944 text, An American Dilemma, that the promise of the American Dream would eventually be fulfilled, solving the

\footnotetext{
110 Ibid.,118. It is quite possible that Williams was influenced here by the work of Herbert Aptheker on slave revolts. Herbert Aptheker, American Negro Slave Revolts (New York: Columbia University Press, 1943).

111 Peniel E. Joseph, Waiting 'til the Midnight Hour: A Narrative History of Black Power in America (New York: Henry Holt and Company, 2006), 199.
} 
problem of race relations in the United States. Carmichael argued that in fact there was no "American dilemma" "because black people in this country form a colony, and it is not in the interest of the colonial power to liberate them." 112 "Colonialism" was a description no doubt influenced by popular anti-colonial struggles around the world.

An essential part of Black Power was its call for racial separatism approximating the "separatism" practiced by other ethnic groups in American history. As Christopher Lasch pointed out in his 1968 essay on Black Power in the New York Review of Books, this coexisted with and contradicted the other theme in Black Power, namely its call for guerrilla warfare against colonialism. ${ }^{113}$ Lasch's criticism notwithstanding, both of these tendencies drew heavily on a picture of the past. Carmichael claimed the "separatist" trend was widespread and noted that "Throughout this country, vast segments of the black communities are beginning to recognize the need to assert their own definitions, to reclaim their history, their culture; to create their own sense of community and togetherness." ${ }^{114}$ Carmichael presented this not as a prescription but in recognition of what was going on around him. Although he did not offer specifics, he claimed that African Americans "are becoming aware that they have a history which pre-dates their forced introduction

\footnotetext{
112 Carmichael and Hamilton, 5.

113 Christopher Lasch, “A Special Supplement: The Trouble with Black Power,” New York Review of Books, February 19, 1968.

114 Carmichael and Hamilton, 37.
} 
to this country." 115 In other words, African Americans were simply following the path the Italians, Irish, Jews, and other immigrant groups had trod before them, engaging in a cultural reclamation project and constructing a national identity.

As in South Africa, this memory was recalled in opposition to dominant forms of white memory, which Carmichael claimed had been used to keep blacks in submission. "Too long have [African Americans] been kept in submission by being told they had no culture, no manifest heritage, before they landed on the slave auction blocks in this country. If black people are to know themselves as a vibrant, valiant people, they must know their roots." 116 Grounded by a sense of history, the "new consciousness" would be the "vital first step" in tackling the problem of race in America. ${ }^{117}$ Malcolm X offered a similar interpretation, claiming that black schoolchildren were taught nothing about African American contributions to history: "When we send our children to school in this country they learn nothing about us other than that we used to be cotton pickers. Every little child going to school thinks his grandfather was a cotton picker."118

Strategic visions likewise rested on a particular form of memory. Rejecting interracial collaboration on the grounds that the parties had differing goals, Carmichael reexamined the coalitions founded by the late nineteenth century

\footnotetext{
115 Ibid., 38.

116 Ibid., 38-39.

117 Ibid., 39.

118 Malcolm X, "The Founding Rally of the OAAU," By Any Means Necessary: Speeches and Writings (New York: Pathfinder Press, 1992), 28-29.
} 
Populists. In one instance, the aims of the Colored Farmers' Alliance and Cooperative Union along with the Northern and Southern Farmers' Alliance seemed to be the same. But on the issue of guaranteeing the voting rights of Southern blacks, the groups differed. Carmichael also cited the case of Tom Watson, the white Georgian political leader who once favored black and white collaboration but later was a staunch supporter of the Klan. ${ }^{119}$ Assata Shakur, a Black Panther Party member, concurred, though did not offer specifics. For Shakur, history demonstrated that appealing to the morality of the oppressor was never a successful strategy. Whites in the North and South alike benefited from the oppression of blacks. ${ }^{120}$ Like many of her contemporaries, Shakur read African-American history widely, but the content of that history seems to have differed little from the men she largely talked with. One exception to this is that Shakur found most of the African women's names to be very different from the men's, which usually translated as "strong, warrior, man of iron, brave, etc." She chose "Assata" because it meant "She who struggles."121

Angela Davis, who was active in Black Panther and Communist Party circles, looked much more closely at the history of enslaved African American women. Davis wrote in 1971 that enslaved men and women shared a "deformed equality of equal oppression" out of which women "would be prepared to ascend to the same levels of

\footnotetext{
119 Carmichael and Hamilton, 66-70.

${ }^{120}$ Assata Shakur, Assata Shakur: An Autobiography (London: Zed Books, 1987), 139. 121 Shakur, 186.
} 
resistance which were accessible to her men." In Davis' telling, women participated equally in acts of petit and grand marronage, and with the contribution of both men and women, the slave community "could achieve heights unscaleable within the families of the white oppressed or even within the patriarchal kinship groups of Africa."122 Davis lamented the lack of study of the role of black enslaved women in resisting slavery, noting only that scholars would occasionally mention that Gabriel's wife helped Gabriel plan his 1800 rebellion. Davis too relied on the work of Herbert Aptheker in stressing how widespread slave revolt had been. But enslaved women could also resist by poisoning their master or burning down the plantation. ${ }^{123}$ Importantly, Davis published the article only months after the death of her lover, the Black Panther George Jackson died in prison only three days before his murder trial was set to begin. Davis dedicated her article to Jackson— "one of the most admirable black leaders to emerge from the ranks of our liberation movement" — and it may well have been in the light of his death that Davis looked to the history of enslaved women to examine the place of African American women in the present struggle. ${ }^{124}$

Huey Newton, the Minister of Self-Defense of the Black Panther Party, went further than Carmichael, arguing in 1967 that, "the black people in America are the only people who can free the world, loosen the yoke of colonialism and destroy the

\footnotetext{
122 Angela Davis, "Reflections on the Black Woman's Role in the Community of Slaves," The Angela Y. Davis Reader, 115.

123 Davis, 118-119.

124 Ibid., 111.
} 
war machine." Based in Oakland, California, the Black Panthers were a revolutionary leftist organized that firmly rejected the nonviolence of the SCLC, SNCC and others. In a programmatic essay, "In Defense of Selfdefense," Newton relied on a particular reading of history to make his claims. ${ }^{125}$ The most striking element of the article is the accompanying photo of Newton, who is sitting with a rifle resting vertically on the floor in his right hand, and a spear similarly situated in his left hand. The photo is remarkable for its juxtaposition of modern and premodern elements, the gun and the spear being the most obvious. While Newton wears a leather jacket and his revolutionary beret, he is sitting on what appears to be an ersatz African throne, while the floor is covered with a zebra skin. Old and new merge in the steel shields flanking Newton, in shape representing old, but fabricated with modern methods. That the image was meant to evoke other anticolonial struggles in a vague manner-Kenya or South Africa?-becomes clear when Newton boasts that "now there is a universal rebellion against [the] continued rule and power [of the colonized whites]."126

But it was specifically to American history that Newton looked for his rhetorical inspiration and defense of self-defense, the year 1776 and the American Revolution being most important. Newton held up the example of the "colonized" white English in the 1770s who, "felt he had no choice but to raise the gun in defense of the welfare of the colonized people." Newton here uses the language of

125 Huey P. Newton, "In Defense of Selfdefense," The Black Panther, Vol. 1, No. 3, June 20, 1967, 3-4.

126 Newton, 3. 
Mao Tse-Tung, whom he also quotes: "We are advocates of the abolition of war; but war can only be abolished through war, and in order to get rid of the gun it is necessary to take up the gun." Newton is vague on African American history, noting only that "The blood, sweat, tears, and suffering of black people are the foundation of the wealth and power of the United States of America." But American blacks are the crucial linchpin in the worldwide imperialist system in Newton's view-the "slavery of blacks...provides the oil for the machinery of war that America uses to enslave the people of the world." His reference to slavery echoes the thought of Williams and Malcolm X, but the history of slavery is also essential for the future of America: "We were forced to build America and if forced to we will tear it down."127 Only those ignorant of the true black history would think otherwise. In an accompanying list of demands such as freedom, an education "that teaches us our true history," full employment, shelter, juries by peers from the black community among others, The Black Panther noted, “To those poor souls who don't know black history, the beliefs and desires of the Black Panther Party for Self Defense may seem unreasonable," but after four hundred years, the party was tired of hearing that "these things take time."128

In the same issue, Mek Nimr took issue with the commonly held belief that the first Africans arrived in what became the United States in 1619. Relying on Herbert Aptheker, Nimr argued "that the history books are wrong about this

\footnotetext{
127 Newton, 3-4.

128 Unauthored, "What We Want Now! What We Believe!” The Black Panther, Vol. 1, No. 3, June 20, 1967, 3.
} 
important fact, as they are about so many others regarding anything pertaining to the 'dark continent.'” Nimr approvingly quoted Aptheker, who wrote that in 1526 Lucas Vasquez de Ayllon founded a settlement in present day South Carolina, which soon became home to the first slave revolt in what became the United States. ${ }^{129}$

Elsewhere, Newton and the Black Panther Party were more critical of the American Revolution and its legacy. Executive Mandate Number One, "which was to be our message to the Black communities," Newton said, was clear about this. There was only one policy toward "people of color": "repression, genocide, terror, and the big stick," a policy that could be traced back to "[t]he enslavement of Black people at the very founding of this country." 130 Slavery thus represented an original stain on the nation.

Slavery had an important role to play in Newton's defense at his 1968 trial, where he was charged with the death of Oakland police officer John Frey. Newton's invocation of the black past while on the stand bears comparison with Mandela's attempt to do the same in South Africa. In Newton's view, blacks were a colonized people who were used by the white power structure when it suited them. Thus, they were enslaved, and with emancipation, given no land with nowhere to go. During the Second World War they were hired in defense industries, and promptly let go with the war's end. As other activists have attested, past and present collapsed

\footnotetext{
129 Mek Nirm, "Were Black People First," The Black Panther Vol. 1, No. 3, June 20, 1967, 6.

${ }^{130}$ Huey Newton, Revolutionary Suicide, 156.
} 
under the strain of the perceived continuous brutality of both tenses. While on the stand and explaining black history, Newton recalls in his autobiography, "I forgot that I was on trial for my life. The subjects were so real and important to me that I would get lost in what I was saying."131

Like Newton, the spirit of '76 was also important to Malcolm X, who by 1964 had broken with Elijah Muhammad's Nation of Islam and was immensely popular in his own right among many African Americans. At a meeting in Paris in 1964, Malcolm X was very discriminating when it came to choosing heroes. Asked if it was important for blacks to know about Frederick Douglass and slave revolts, Malcolm X responded affirmatively, but stressed what he saw as the enormous gulf between the two. The escaped slave Frederick Douglass was an influential abolitionist, and following the Civil War continued writing and speaking on behalf of the freedmen following a legalistic framework. Malcolm X took no issue with Douglass, saying that Douglass "was great." However, he would have rather learned about the leader of the Haitian Revolution, Toussaint L'Ouverture, because "We need to be taught about people who fought, who bled for freedom and made others bleed." The questioner responded that Crispus Attucks was both black and the first to die in the American Revolution, and indeed Attucks had commonly been a central part of African American collective memory. Malcolm X's problem was that like other African American soldiers in Vietnam or the South Pacific, "He wasn't shot for Negroes. He was shot for America." Black heroes should be individuals "who have died fighting

131 Newton, 249-250. 
for the benefit of Black people." This was not taught in schools, but a "history we want to learn." 132

History was also essential to understanding relations within the black community, Malcolm X argued. During slavery, he claimed, masters did not need to kill outspoken blacks like himself. Rather, they would send "some old house Negro along behind him to undo what he said." The house slaves, according to Malcolm X, loved their master more than the master loved himself. On the contrary, field slaves "had nothing to lose." This distinction had not disappeared in the intervening century: "today you still have house Negroes and field Negroes. I'm a field Negro," Malcolm proudly proclaimed. ${ }^{133}$ Huey Newton also invoked this distinction at his 1968 trial, claiming that the one black on his jury was a "house nigger," being an executive at the Bank of America. The district attorney likely felt he "could be counted on because of his status and his ambition to go farther in the white world."134

Malcolm X's view of history highlights the importance of Islam, and the rejection of Christianity, in his vision. Since the $16^{\text {th }}$ century, white men bearing the cross had never followed "the true manner and spirit of Christ's teachings-meek, humble, and Christ-like." White men had long branded ancient non-white cultures

\footnotetext{
132 Malcolm X, "At A Meeting in Paris," By Any Means Necessary: Speeches and Writings (New York: Pathfinder Press, 1992), 124-125.

133 Malcolm X, Malcolm X on Afro-American History (New York: Pathfinder Press, 1990), 75-76.
}

134 Newton, 218. 
and religions as "heathen" and "pagan." "The stage thus set, he then turned upon his non-white victims his weapons of war."135

While Malcolm, Newton and Carmichael relied on a vision of the past for their political and strategic project, the past could be a fraught place for white writers to visit during the black power era. Easily the best-known case is of the reaction to the white southern novelist William Styron's 1967 The Confessions of Nat Turner. The novel is concerned with Nat Turner's 1831 slave rebellion in Virginia, one of the bloodiest in American history.

The negative reaction from many black writers was swift, and is primarily contained in the 1968 volume edited by John Henrik Clarke, William Styron's Nat Turner: Ten Black Writers Respond. ${ }^{136}$ Clarke's introduction begins with an instructive quotation from Herbert Aptheker: "History's potency is mighty. The oppressed need it for identity and inspiration; oppressors for justification, rationalization and legitimacy. Nothing illustrates this more clearly than the history writing on the American Negro people."137 It was in this heightened historical consciousness described by Aptheker that the charges against Styron-and the charges were personal, not just literary—were leveled.

\footnotetext{
135 Newton, 67.

136 John Henrik Clarke, ed., William Styron's Nat Turner: Ten Black Writers Respond (Boston: Beacon Press, 1968). 137 Aptheker quoted in Clarke, vii.
} 
There were three main criticisms of The Confessions of Nat Turner. The first and most pressing was that Styron had not hewn closely to what were purported to be the facts about Turner's 1831 revolt. The second had to do with the white Southerner Styron appropriating a black voice-the Nat Turner in the novel was really just a "Hamlet-like white intellectual in blackface,"138 Lerone Bennett charged. Third was the highly sexualized element to Turner, who in the novel lusted after "a pure white belle with swishing skirts,"139 uncomfortably echoing the stereotype of the black male as rapist. John Killens argued that it was "impossible for the slavemaster's grandson ['Master William Styron'] to see the revolutionary black man in the sense that Gabriel saw himself, as the 'George Washington' of his people." For Killens the past was hardly distinguishable from the present: "There are thousands of Nat Turners in the city streets today, and the ranks of freedom-fighters are increasing every moment." John Williams claimed in what was surely a minority opinion that Styron was an apologist for slavery. Why else had "free Negroes suffered far more than did slave Negroes" in the Confessions of Nat Turner? ${ }^{140}$ Conversely, Styron could be accused of failing to distinguish the past from the present. Williams was bothered by the fact that only black characters in the novel spoke in curse words, words not likely heard in the early nineteenth century. "Styron has transplanted the present back into the past." ${ }^{141}$ Nearly all of the

\footnotetext{
138 Lerone Bennett, Jr., "Nat's Last White Man," in Clarke.

139 Quoted in Clarke, vii.

140 John Williams, 48, in Clarke.

141 Williams, 49, in Clarke.
} 
respondents faulted Styron for singling out Turner's revolt as the only one of any moment, citing the Stono Rebellion of 1739, Gabriel's rebellion of 1802, or Denmark Vesey's 1822 rebellion. Many of the writers relied on Herbert Aptheker's scholarship to make their claim. Another key theme in the collection was the sense of ownership over Turner and his legacy, often referring to "our" Turner. To drive the point home about getting the past "right," Clarke included in an appendix the full text of The Confessions of Nat Turner as Reported to Thomas R. Gray. It was only decades later that some black intellectuals like Cornel West and Henry Louis Gates Jr. came to view Styron's Nat Turner more favorably. ${ }^{142}$

The slave past was also important to James Cone's influential attempt to formulate a distinct Black Power theology in his 1969 volume, Black Theology and Black Power. ${ }^{143}$ Writing only a year after the assassination of Martin Luther King Jr., whose theology and political strategy rested heavily on non-violence, Cone's monograph came as a manifest challenge to King's thought and legacy. Cone begins his chapter on the black church simply by noting, "The black church was born in slavery." Despite writing after the publication of Melville Herskovits' influential 1941 work, The Myth of the Negro Past, which argued for cultural continuity in the forced migration from Africa to the Americas, Cone offered no ambiguity in his take

\footnotetext{
142 Jess Row, "Styron's Choice," The New York Times, September 5, 2008, BR27. 143 James H. Cone, The Black Church and Black Power (New York: The Seabury Press, 1969).
} 
on African American history. ${ }^{144}$ Slaves were "completely stripped of their African heritage as they were enslaved by the 'Christian' white man." ${ }^{145}$ Cone resolved the ambiguity of the black church being formed by Christian masters rather crudely but powerfully by focusing on slave agency. When Cone argued that " $[t]$ he black church was the creation of a black people whose daily existence was an encounter with the overwhelming and brutalizing reality of white power," he could easily have been referring to his present, 1969. ${ }^{146}$ Slave religion was not entirely escapist, Cone argued, nor did it accept the white view that "God ordained slavery for them."147 Cone placed the current struggles of Black Power as descending from the black church forged in slavery, and thus the black church could be seen as the "precursor of Black Power." 148 Cone recognized the irony in blacks accepting the "white master's religion [as] the best way to freedom" but he goes into some detail about the history of separatist churches, which were formed because of the racism attached to white churches. ${ }^{149}$ But this discussion of the history of the black church was hardly incidental to Cone's take on the present. "The pre-Civil War black ministers had no trouble breaking the law when they saw human life at stake," he wrote, but the black church has failed to keep up with contemporary developments.

\footnotetext{
${ }^{144}$ Melville J. Herskovits, The Myth of the Negro Past (New York: Harper and Row, 1941).

145 Cone, 91.

146 Ibid., 92.

147 Ibid., 93.

148 Ibid., 94.

149 Ibid., 94.
} 
Combining Biblical metaphor with Mao, Cone pointed out that "Blacks are no longer prepared to turn the other cheek; instead, they are turning the gun."150

Like the transnational movement of Stokely Carmichael's thought, the work of James Cone was similarly influential in the development of Black Consciousness theology in South Africa. In a process similar to the way slaves in the United States became converted to the master's religion, many black South Africans had become Christianized through missionary work, but in both cases Christianity could be used not to keep blacks in submission, as Malcolm X argued, but as a shield against white supremacy. Members of the University Christian Movement (UCM) turned to Cone in the context of UCM President Justice Motolo's 1970 speech, which argued, "if the UCM should be Christian, it should be about liberation."151 UCM member Sabelo Ntwasa wrote to Cone in January 1971, remarking that Cone's theology had "set in motion a radical re-think of Christianity in our fascist country."152 This mimesis hints at the links between South Africa and the United States in this period that have yet to be fully explored by historians.

American critics of Black Power responded with their own readings of history to critique those offered by Black Power leaders. Bayard Rustin, one of the leaders of the Civil Rights campaign of the 1960s, offered a critique of what he called black separatism in Harper's magazine in 1970. Rustin disputed the efforts of some

\footnotetext{
150 Ibid.,114.

151 Quoted in Magaziner, The Law and the Prophets, 101.

152 Quoted in Magaziner, 102.
} 
to craft a separate black history, one unconnected from American history. AfricanAmerican history had been relegated to second-class status previously, Rustin observed, and contemporaries were unwittingly making the same mistake by insisting on a separate black history. ${ }^{153}$ In Martin Luther King Jr.'s view, freedom would be won "because both the sacred heritage of our nation and the eternal will of the almighty God are embodied in our echoing demands."154 King believed that Black Power's focus on the slave past accounted for, but did not justify, "uncivil disobedience."155

The black dramatist and intellectual Harold Cruse dismissed the entire project to reclaim a revolutionary black past. For Cruse, the black past dating to the Harlem Renaissance of the 1920s was fatally compromised by a tired nationalist/integrationist binary and too often coopted by white Communists and the black bourgeoisie. As for the memory of slave revolts like those led by Denmark Vesey or Nat Turner, "Everyone from Communist whites to nationalist blacks sees in these slave uprisings anything they want to see."156 Further, Cruse had contempt for those who could not distinguish between a mere slave rebellion and a slave

153 Bayard Rustin, “The Failure of Black Separatism,” Harper's, January 1970. 154 Martin Luther King Jr., "Remaining Awake Through a Great Revolution” (sermon, National Cathedral (Episcopal), Washington, DC, March 31, 1968.

155 Martin Luther King, Jr., Where Do We Go From Here: Chaos or Community?, in James M. Washington, ed., A Testament of Hope: The Essential Writings and Speeches of Martin Luther King Jr., (New York: HarperCollins, 1991), 580.

156 Harold Cruse, The Crisis of the Negro Intellectual, 350. 
revolution. Ultimately for Cruse the past needed to be studied only so African Americans could be rid of its failures.

Black Power and its critics both relied on particular forms of collective memory to articulate diagnoses of the present and develop strategies for escaping the problems of the past. Indeed, some writers relied so heavily on collective memory that the distinction between the past and present began to collapse, as in Cone's theological writing, for instance, or Huey Newton at trial. Nearly all looked to the history of slavery in America to make their arguments, often depicting the rebellious male slave as their archetype. The role of religion and its fraught history with white supremacy also became an issue that thinkers in the Black Power era wrestled with. Some thinkers like Robert F. Williams and Malcolm X rejected Christianity as being a religion of whites used to oppress blacks, while others like James Cone attempted to formulate a new black Christian theology. All chiefly looked to the past to make their arguments. The past could also be a strategic roadmap, as Stokely Carmichael argued it was the basis for a rejection of interracial political coalition. All leaned on the past to support their struggle against white supremacy. 


\section{Conclusion}

Studying the efforts to reinvigorate popular and collective memories found in the militant turns in 1960s American and South African history demonstrates that while activists in both countries relied on particular memories of past struggle and oppression, the memory they drew on was highly localized. In South Africa, MK members constructed a memory of linkage to the colonial encounter with Europeans regardless of national original, be it Xhosa, Zulu, or otherwise. In the United States, activists drew on a memory of slave revolt particular to the United States. Both supporters and critics of Black Power drew on Christianity and the history of the black church, while a religious component did not exist in Umkhonto we Sizwe's discourses and embodiments of memory. However, partly in response to James Cone's theology, the Black Consciousness movement that filled the political vacuum left by MK and the ANC was theologically inspired.

Memory was also used to navigate relations within the liberation movements. Malcolm X did so with his discussion of field and house slaves, while Mandela appealed to both Xhosa and Zulu history, and an African past that may have appealed to his PAC competitors. This suggests that a particular reading of history may have contributed to the process of race-making in both countries by delimiting who was and who was not a member of a race or ethnicity. In the following Black Consciousness era in South Africa, this would be important, as Black Consciousness 
had a very wide view of who was "black." In both cases, activists drew on the past to contest what they saw as hegemonic memories that underpinned white supremacy.

While memory was an important rhetorical tool, it also had significant practical and strategic implications. In the United States, Black Power thinkers like Stokely Carmichael, Malcolm X, and James Cone rejected interracial political coalitions as an effective strategy based on a reading of history. History showed non-violent protest too was ineffective in combatting white supremacy. Rather, in both countries, violence used in self-defense or in response to colonizing aggressors was seen as the only viable move.

Memory could be embodied and practiced as well as written down. In the United States, this could be seen in the practice of rejecting one's "slave name" like Malcolm X and Assata Shakur did, or as Huey Newton did in his "revolutionary" pose for a the camera, appropriating the symbols of a supposedly ancient Africa. Nelson Mandela did likewise when he arrived at the treason trial wearing his royal kaross while a praise singer detailed his ancestry just outside the courtroom. Irrespective of the specific content of the collective memory invoked by both Black Power and MK, the particular form that memory took in both instances suggests that these are strategies that other subaltern groups may have used as well.

This thesis is a comparative analysis of only one pair of histories of collective memory confined to two nations and a decade and a half: as Oliver Tambo and Albert Luthuli show compared to Mandela, the memory that leaders attempt to use 
in the service of politics can change rapidly. The histories of black collective memory in both the United States and South Africa remain underdeveloped, and transnational perspectives of memory, only hinted at here, deserve further investigation. While this thesis has been keen to the ways in which black memory can develop in opposition to white memory, other histories are needed which closely examine the dialectical relationship of both white and black memory, as well as the memory of groups like the Cape Coloureds who disrupt this binary. Such work, only begun here, will be instrumental in excavating the history of black liberation as well as black subjectivity across the African diaspora. 
Bibliography

\section{Primary Sources}

African Communist

Alexander, Margaret Walker. On Being Female, Black and Free: Essays by Margaret Walker. Knoxville, TN: University of Tennessee Press, 1997.

Aptheker, Herbert. American Negro Slave Revolts. New York: Columbia University Press, 1943.

Baraka, Imamu Amiri. Home: Social Essays. New York: William Morrow and Company, 1966.

Barbour, Floyd, ed. The Black Power Revolt: A Collection of Essays. Boston: Extending Horizons Books, 1968.

Bay State Banner

Bernstein, Hilda. The World That Was Ours: The Story of the Rivonia Trial. London: SAWriters, 1989.

Biko, Steve. I Write What I Like: Selected Writings. Chicago: University of Chicago Press, 1972.

Black Scholar

Bormann, Ernest G. Forerunners of Black Power: The Rhetoric of Abolition. New Jersey: Prentice-Hall, 1971.

Carmichael, Stokely and Charles V. Hamilton. Black Power: The Politics of Liberation. New York: Random House, 1967.

Carmichael, Stokely. Stokely Speaks. Lawrence Hill, 1965.

Chicago Defender

Clarke, John Henrik, ed. William Styron's Nat Turner: Ten Black Writers Respond. Boston: Beacon Press, 1968.

Cleaver, Eldridge. Soul on Ice. New York: McGraw-Hill, 1968.

Cone, James H. Black Theology and Black Power. New York: The Seabury Press, 1969.

Cruse, Harold. Rebellion or Revolution? New York: William Morrow and Company, 1968. 
Cruse, Harold. The Crisis of the Negro Intellectual: A Historical Analysis of the Failure of Black Leadership. New York: William Morrow and Company, 1967.

Ellison, Ralph. The City in Crisis. New York: A. Philip Randolph Educational Fund, 1966.

Fanon, Frantz. Black Skin, White Masks. Translated by Richard Philcox. New York: Grove Press, 1952.

Fanon, Frantz. The Wretched of the Earth. Translated by Richard Philcox. New York, Grove Press, 1963.

Fighting Talk

Freedomways

Genovese, Eugene. In Red and Black: Marxian Explorations in Southern and AfroAmerican History. New York: Pantheon Books, 1968.

Genovese, Eugene. "The Influence of the Black Power Movement on Historical Scholarship: Reflections of a White Historian." Daedalus, 1, Spring, 1970.

Harper's

Hayden, Tom. Rebellion in Newark: Official Violence and Ghetto Response. New York: Random House, 1967.

Herskovits, Melville J. The Myth of the Negro Past. New York: Harper and Row, 1941.

James, Joy. The Angela Y. Davis Reader. Malden, Mass.: Blackwell Publishers, 1998.

Kasrils, Ronnie. Armed and Dangerous: My Undercover Struggle Against Apartheid. Oxford: Heinemann, 1993.

Killian, Lewis M. The Impossible Revolution? Black Power and the American Dream. New York: Random House, 1968.

King Jr., Martin Luther. The Essential Writings and Speeches of Martin Luther King Jr. James M. Washington, ed. New York: HarperCollins, 1991.

Lasch, Christopher. "A Special Supplement: The Trouble with Black Power." The New York Review of Books. February 19, 1968.

Lester, Julius. Look Out Whitey, Black Power's Gon' Get Your Mama. New York: Dial Press, 1968.

Mandela, Nelson. Conversations with Myself. New York: Farrar, Straus and Giroux, 2010. 
Mandela, Nelson. Long Walk to Freedom. New York: Little, Brown, and Company, 1994.

Mtolo, Bruno. Umkhonto we Sizwe: The Road to the Left. Durban: Drakensberg Press, 1966.

Newton, Huey P. Revolutionary Suicide. New York: Penguin Books, 1973.

Newton, Huey Percy. Essays from the Minister of Self Defense. Privately published, 1968.

Oakland Post

Peeks, Edward. The Long Struggle for Black Power. New York: Charles Scribner's Sons, 1971.

Rivonia Trial Papers

Rustin, Bayard. Down the Line: The Collected Writings of Bayard Rustin. Chicago: Quadrangle Books, 1971.

Sacramento Observer

San Francisco Sun Reporter

Sechaba

Shakur, Assata. Assata Shakur: An Autobiography. London: Zed Books, 1987.

The State v. Nelson Mandela and Others.

South African Democracy Education Trust. The Road to Democracy in South Africa, Volume 1, 1960-1970. Pretoria: Unisa Press, 2010.

Styron, William. The Confessions of Nat Turner: A Novel. New York: Random House, 1967.

Tambo, Adelaide. Preparing for Power: Oliver Tambo Speaks. London: Hansib, 2004.

The Black Panther

Truth and Reconciliation Commission of South Africa Report. 21 March 2003.

Unauthored. Memorandum: a study in political heresy. South African Communist Party, 1958.

Unauthored. The Pan African Congress Venture in Retrospect. Unity Movement of South Africa, 1960.

Williams, Robert F. Negroes with Guns. New York: Marzani and Munsell, 1962. 
X, Malcolm. By Any Means Necessary: Speeches and Writings. New York: Pathfinder Press, 1992.

X, Malcolm. Malcolm X on Afro-American History. New York: Pathfinder Press, 1990.

\section{Secondary Sources}

Alexander, Jeffrey C. et al. Cultural Trauma and Collective Identity. Berkeley: University of California Press, 2004.

Alexander, Peter and Rick Halpern. "Comparing Race and Labour in South Africa and the United States." Journal of Southern African Studies. Vol. 30, No. 1, Special Issue: Race and Class in South Africa and the United States (Mar., 2004), 5-18.

Alkebulan, Paul. Survival Pending Revolution: The History of the Black Panther Party. Tuscaloosa: The University of Alabama Press, 2007.

Appadurai, Arjun. “The Past as a Scarce Resource." Man. New Series, Vol. 16, No. 2 (Jun., 1981), 201-219.

Austin, Curtis J. Up Against the Wall: Violence and the Unmaking of the Black Panther Party. Fayetteville: University of Arkansas Press, 2006.

Barton, Craig Evan, ed. Sites of Memory: Perspectives on Architecture and Race. New York: Princeton Architectural Press, 2001.

Blight, David W. Race and Reunion: The Civil War in American Memory. Cambridge: Harvard University Press, 2001.

Bozzoli, Belinda. Theatres of Struggle and the End of Apartheid. Athens: Ohio University Press, 2004.

Brown, Christopher. Moral Capital: Foundations of British Abolitionism. Chapel Hill: University of North Carolina Press, 2006.

Brundage, Fitzhugh. The Southern Past: A Clash of Race and Memory. Cambridge: Harvard University Press, 2005.

Bush, Rod. We Are Not What We Seem: Black Nationalism and Class Struggle in the American Century. New York: New York University Press, 1999.

Callinicos, Luli. Oliver Tambo: Beyond the Engeli Mountains. Claremont, South Africa: David Philip, 2004. 
Campbell, James T. Middle Passages: African American Journeys to Africa, 1787-2005. New York: The Penguin Press, 2006.

Cell, John W. The Highest Stage of White Supremacy: The Origins of Segregation in South Africa and the American South. Cambridge: Cambridge University Press, 1982.

Chakrabarty, Dipesh. Provincializing Europe: Postcolonial Thought and Historical Difference. Princeton: Princeton University Press, 2000.

Chappell, David L. Stone of Hope: Prophetic Religion and the Death of Jim Crow. Chapel Hill: University of North Carolina Press, 2004.

Chayes, Antonia and Martha Minow, eds. Imagine Coexistence: Restoring Humanity After Violent Ethnic Conflict. San Francisco: Wiley Bass, 2003.

Chipkin, Ivor. Do South Africans Exist? Nationalism, Democracy and the Identity of 'the People.' Johannesburg: Wits University Press, 2007.

Clegg, Claude Andrew III. An Original Man: The Life and Times of Elijah Muhammad. New York: St. Martin's Press, 1997.

Cobbing, Julian. "The Mfecane as Alibi: Thoughts on Dithakong and Mbolompo." The Journal of African History. Vol. 29, No. 3 (1988), 487-519.

Collier-Thomas, Bettye and V.P. Franklin, eds. Sisters in the Struggle: African American Women in the Civil Rights—Black Power Movement. New York: New York University Press, 2001.

Comaroff, John and Jean Comaroff. Ethnicity Inc. Chicago: University of Chicago Press, 2009.

Conyers, James L. Jr., ed. Engines of the Black Power Movement: Essays on the Influence of Civil Rights Actions, Arts, and Islam. Jefferson, NC: McFarland \& Company, 2007.

Coombes, Annie E. History after Apartheid: Visual Culture and Public Memory in a Democratic South Africa. Durham: Duke University Press, 2003.

Coombes, Annie E., ed. Rethinking settler colonialism: History and memory in Australia, Canada, Aotearoa New Zealand and South Africa. Manchester: Manchester University Press, 2006.

Cooper, Frederick. "Race, Ideology, and the Perils of Comparative History." The American Historical Review. Vol. 101, No. 4 (Oct., 1996), 1122-1138.

Countryman, Matthew J. Up South: Civil Rights and Black Power in Philadelphia. Philadelphia: University of Pennsylvania Press, 2006. 
Crais, Clifton. The Politics of Evil: Magic, State Power, and the Political Imagination in South Africa. Cambridge: Cambridge University Press, 2002.

Crapanzano, Vincent. Waiting: The Whites of South Africa. New York: Random House, 1985.

Crane, Susan. "Writing the Individual Back into Collective Memory." American Historical Review. Vol. 102, No. 5 (Dec. 1997), 1372-1385.

Davis, William C. The Cause Lost: Myths and Realities of the Confederacy. Lawrence, Kansas: University Press of Kansas, 1996.

Dlamini, Jacob. Native Nostalgia. Auckland Park: Jacana Media, 2009.

Dooley, Brian. Black and Green: The Fight for Civil Rights in Northern Ireland and Black America. London: Pluto Press, 1998.

Doxtader, Erik. With Faith in the Works of Words: The Beginnings of Reconciliation in South Africa, 1985-1995 (East Lansing: Michigan State University Press, 2009

Dubow, Saul. The African National Congress. Stroud: Sutton Publishing, 2000.

Dwyer, Owen and Derek Adelman. Civil Rights Memorials and the Geography of Memory. Athens: University of Georgia Press, 2008.

Elphick, Richard and Rodney Davenport, eds. Christianity in South Africa: A Political, Social, and Cultural History. Berkeley: University of California Press, 1997.

Fabre, Genevieve and Robert O'Meally, eds. History and Memory in African-American Culture. New York: Oxford University Press, 1994.

Fatton, Robert. Black Consciousness in South Africa: the Dialectics of Ideological Resistance to White Supremacy. Albany: State University of New York Press, 1986.

Fellman, Michael. In the Name of God and Country: Reconsidering Terrorism in American History. New Haven: Yale University Press, 2010.

Fergus, Devin. Liberalism, Black Power, and the Making of American Politics, 19651980. Athens: The University of Georgia Press, 2009.

Field, Sean, Renate Meyer and Felicity Swanson (eds.) Imagining the City: Memories and Cultures in Cape Town. Cape Town: HSRC Press, 2007.

Foster, Gaines. Ghosts of the Confederacy: Defeat, the Lost Cause, and the Emergence of the New South, 1865-1913. Oxford: Oxford University Press, 1988.

Frederikse, Julie. The Unbreakable Thread: Non-Racialism in South Africa. Bloomington: Indiana University Press, 1990. 
Fredrickson, George M. Black Liberation: A Comparative History of Black Ideologies in the United States and South Africa. Oxford: Oxford University Press, 1995.

Fredrickson, George M. White Supremacy: A Comparative Study in American and South African History. Oxford: Oxford University Press, 1981.

French, Scot. The Rebellious Slave: Nat Turner in American Memory. Boston: Houghton Mifflin Company, 2004.

Gerhart, Gail M. Black Power in South Africa: The Evolution of an Ideology. Berkeley: University of California Press, 1978.

Goldberg, David and Trevor Giffey, eds. Black Power at Work: Community Control, Affirmative Action, and the Construction Industry. Ithaca: Cornell University Press, 2010.

Graybill, Lyn S. Religion and Resistance Politics in South Africa. Ann Arbor: University of Michigan Press, 1995.

Greenstein, Ran, ed. Comparative Perspectives on South Africa. London: Macmillan Press, 1998.

Guy, Jeff. Remembering the Rebellion: the Zulu Uprising of 1906. Scottsdale, South Africa: University of KwaZulu-Natal Press, 2006.

Halbwachs, Maurice. On Collective Memory, translated by Lewis A. Coser. Chicago: University of Chicago Press, 1992.

Hall, Jacquelyn Dowd. "The Long Civil Rights Movement and the Political Uses of the Past." The Journal of American History. Vol. 91, No. 4 (Mar., 2005), pp. 12331263

Hamilton, Carolyn, ed. The Mfecane Aftermath: Reconstructive Debates in Southern African History. Johannesburg: Witswatersrand University Press, 1995.

Hamilton, Carolyn. Terrific Majesty: The Powers of Shaka Zulu and the Limits of Historical Invention. Cambridge: Harvard University Press, 1998.

Hayner, Priscilla B. Unspeakable Truths: Confronting State Terror and Atrocity. New York: Routledge, 2002.

Hill, Lance. The Deacons for Defense: Armed Resistance and the Civil Rights Movement. Chapel Hill: The University of North Carolina Press, 2004.

Hopkins, Dwight N., ed. Black Faith and Public Talk: Critical Essays on James J. Cone's Black Theology and Black Power. Maryknoll, NY: Orbis Books, 1999.

Horowitz, Tony. Confederates in the Attic: Dispatches from the Unfinished Civil War. New York: Vintage, 1998. 
Howe, Stephen. Afrocentrism: Mythical Pasts and Imagined Homes. London: Verso, 1998.

Jeffries, Hasan Kwame. Bloody Lowndes: Civil Rights and Black Power in Alabama's Black Belt. New York: New York University Press, 2009.

Jeffries, Judson L (ed.). On the Ground: The Black Panther Party in Communities across America. Jackson: University Press of Mississippi, 2010.

Joseph, Peniel E. Waiting 'til the Midnight Hour: A Narrative History of Black Power in America. New York: Henry Holt and Company, 2006.

Kachun, Mitch. Festivals of Freedom: Memory and Meaning in African American Emancipation Celebrations, 1808-1915. Amherst: University of Massachusetts Press, 2003.

Keegan, Timothy. Colonial South Africa and the Origins of the Racial Order. Charlottesville: University of Virginia Press, 1996.

Krog, Antjie. Country of My Skull: Guilt, Sorrow, and the Limits of Forgiveness in the New South Africa. New York: Three Rivers Press, 1998.

LaCapra, Dominick. Writing History, Writing Trauma. Baltimore: The Johns Hopkins University Press, 2001.

Lalu, Premesh. The Deaths of Hintsa: Postapartheid South Africa and the Shape of Recurring Pasts. Cape Town: HSRC Press, 2009.

Lamar, Howard and Leonard Thompson. The Frontier in History: North America and Southern Africa Compared. New Haven: Yale University Press, 1981.

Lichtenstein, Alex. "Southern Identity: A Dissent." Safundi: The Journal of South African and American Studies. Vol. 9, No. 3, July 2008, 311-317.

Lodge, Tom. Black Politics in South Africa since 1945. London: Longman, 1983.

Lodge, Tom. Mandela: A Critical Life. Oxford: Oxford University Press, 2006.

Magaziner, Daniel R. The Law and the Prophets: Black Consciousness in South Africa, 1968-1977. Athens: Ohio University Press, 2010.

Mamdani, Mahmood. Citizen and Subject: Contemporary Africa and the Legacy of Late Colonialism. Princeton: Princeton University Press, 1996.

Marschall, Sabine. Landscape of Memory: Commemorative monuments, memorials and public statuary in post-apartheid South-Africa. Leiden: Brill, 2010. 
Marshall, Anne E. Creating a Confederate Kentucky: The Lost Cause and Civil War Memory in a Border State. Chapel Hill: University of North Carolina Press, 2010.

Marx, Anthony W. Making Race and Nation: A Comparison of the United States, South Africa, and Brazil. Cambridge: Cambridge University Press, 1998.

Marx, Anthony. Lessons of Struggle: South African Internal Opposition, 1960-1990. Oxford: Oxford University Press, 1992.

McCartney, John T. Black Power Ideologies: An Essay in African-American Political Thought. Philadelphia: Temple University Press, 1992.

McElya, Micki. Clinging to Mammy: The Faithful Slave in Twentieth-Century America. Cambridge: Harvard University Press, 2007.

Minardi, Margot. Making Slavery History: Abolitionism and the Politics of Memory in Massachusetts. Oxford: Oxford University Press, 2010.

Murray, Rolland. Our Living Manhood: Literature, Black Power, and Masculine Ideology. Philadelphia: University of Pennsylvania Press, 2007.

Nasson, Bill. "Anglo-Boer War in Post-Apartheid South Africa." Radical History Review. Vol. 78, 1990, pp. 149-165.

Nasson, Bill. "The Unity Movement: Its Legacy in Historical Consciousness." Radical History Review. 1990, pp. 189-211.

Nuttall, Sarah and Carli Coetzee. Negotiating the past: The making of memory in South Africa. Cape Town: Oxford University Press, 1998.

O'Malley, Padraig. Shades of Difference: Mac Maharaj and the Struggle for South Africa. New York: Viking, 2007.

Offenburger, Andrew."The Xhosa Cattle-Killing Movement in History and Literature." History Compass. Vol. 6 Issue 7 (Nov. 2009), 1428-1443.

Ongiri, Amy Abugo. Spectacular Blackness: The Cultural Politics of the Black Power Movement and the Search for a Black Aesthetic. Charlottesville: University of Virginia Press, 2010.

Ortiz, Paul. Emancipation Betrayed: The Hidden History of Black Organizing and White Violence in Florida from Reconstruction to the Bloody Election of 1920. Berkeley: University of California Press, 2005.

Patterson, James T. Brown v. Board of Education: A Civil Rights Milestone and Its Troubled Legacy. New York: Oxford University Press, 2001. 
Peterson, Merrill D. John Brown: The Legend Revisited. Charlottesville: University of Virginia Press, 2002.

Pieres, J.B. The Dead Will Arise: Nongqawuse and the Great Xhosa Cattle-Killing Movement of 1856-7. Bloomington: Indiana University Press, 1989.

Pohlandt-McCormick, Helena. 'I Saw a Nightmare...' Doing Violence to Memory: The Soweto Uprising, June 16, 1976. Columbia University Press, 2006. www.gutenberg-e.org/pohlandt-mccormick.

Rahier, Jean Muteba, Percy C. Hintzen and Felipe Smith. Global Circuits of Blackness: Interrogating the African Diaspora. Urbana: University of Illinois Press, 2010.

Reddy, Thiven. Hegemony and Resistance: Contesting identities in South Africa. Aldershot: Ashgate Publishing, 2000.

Rhodes, Jane. Framing the Black Panthers: The Spectacular Rise of a Black Power Icon. New York: The New Press, 2007.

Rodgers, Daniel T. Age of Fracture. Cambridge: Harvard University Press, 2011.

Romano, Renée and Leigh Raiford, eds. The Civil Rights Movement in American Memory. Athens: University of Georgia Press, 2006.

Row, Jess. "Styron's Choice." The New York Times. September 5, 2008, BR27.

Sampson, Anthony. Mandela: The Authorized Biography. New York: Alfred A. Knopf, 1999.

Schivelbusch, Wolfgang. The Culture of Defeat: On National Trauma, Mourning, and Recovery. Translated by Jefferson Chase. New York: Metropolitan Books, 2001.

Self, Robert 0. American Babylon: Race and the Struggle for Postwar Oakland. Princeton: Princeton University Press, 2003.

Siegel, Micol. "Beyond Compare: Comparative Method after the Transnational Turn." Radical History Review. Issue 91 (Winter 2005), 62-90.

Singh, Nikhil Pal. Black Is a Country: Race and the Unfinished Struggle for Democracy. Cambridge: Harvard University Press, 2004.

Skocpol, Theda and Margaret Somers. "The Uses of Comparative History in Macrosocial Inquiry." Comparative Studies in Society and History, Vol. 22, No. 2 (Apr., 1980), pp. 174-197.

Sparks, Allister Haddon. Tomorrow is Another Country: The Inside Story of South Africa's Road to Change. New York: Hill and Wang, 1995. 
Suttner, Raymond. The ANC Underground in South Africa. Johannesburg: Jacana Media, 2008.

Tannenbaum, Frank. Slave and Citizen. New York: Knopf, 1947.

Thompson, Leonard. The Political Mythology of Apartheid. New Haven: Yale University Press, 1985.

Trouillot, Michel-Rolph. Silencing the Past: Power and the Production of History. Boston: Beacon Press, 1995.

Tyson, Timothy B. Radio Free Dixie: Robert F. Williams and the Roots of Black Power. Chapel Hill: University of North Carolina Press, 1999.

Urquhart, Troy. "Truth, Reconciliation, and the Restoration of the State: Coetzee's Waiting for the Barbarians." Twentieth-Century Literature. Vol. 52, No. 1, Spring 2006, 1-21.

Van Deburg, William L. New Day in Babylon: The Black Power Movement and American Culture, 1965-1975. Chicago: University of Chicago Press, 1992

West, Michael O., William G. Martin, and Fanon Che Wilkins, eds. From Toussaint to Tupac: The Black International since the Age of Revolution. Chapel Hill: The University of North Carolina Press, 2009.

Williams, Hettie V. We Shall Overcome to We Shall Overrun: The Collapse of the Civil Rights Movement and the Black Power Revolt (1962 - 1968). Lanham: University Press of America, 2009.

Wilson, Charles Reagan. Baptized in Blood: The Religion of the Lost Cause, 1865-1920. Athens: University of Georgia Press, 1980.

Witz, Leslie. Apartheid's Festival: Contesting South Africa's National Pasts. Bloomington: Indiana University Press, 2003.

Woodard, Komozi. A Nation Within a Nation: Amiri Baraka (LeRoi Jones) and Black Power Politics. Chapel Hill: University of North Carolina Press, 1999.

Wylie, Dan. Savage Delight: White Myths of Shaka. Pietermaritzburg: University of Natal Press, 2000. 